\title{
'Are we losing touch?' Mainstream parties' failure to represent their voters on immigration and its electoral consequences
}

\author{
David W. Brady ${ }^{1}$, John A. Ferejohn² and Aldo Paparo ${ }^{3 *}$ (D) \\ ${ }^{1}$ Hoover Institution and Stanford Graduate School of Business, Stanford, California, USA, ${ }^{2}$ Department of Law, New York \\ University, New York, New York, USA and ${ }^{3}$ LUISS Guido Carli, Rome, Italy \\ ${ }^{*}$ Corresponding author. Email: apaparo@luiss.it
}

(Received 22 January 2019; revised 10 December 2019; accepted 10 December 2019; first published online 23 January 2020)

\begin{abstract}
In many advanced democracies, mainstream political parties have been disrupted either by the rise of new (populist) parties or by hostile takeovers. In this article we argue that immigration attitudes have had a powerful impact on the strategic environment of political parties and leaders. We show, based on evidence from a comparative study conducted by YouGov in spring of 2015, that immigration attitudes had, by that time, driven a wedge between mainstream parties - those that regularly play a role in government - and their partisans. This 'immigration gap' opened up enormous space for new political movements to form, either inside existing parties or outside. Furthermore, we show that the representation gap on immigration issues is a relevant predictor of vote choice, so that parties are particularly likely to lose votes when they are more distant from their supporters on immigration.
\end{abstract}

Keywords: Immigration; representation; USA; voting behaviour; Western Europe

\section{Introduction: electoral turmoil and the representation gap on immigration}

There is little question that in Western democracies, the mainstream parties - those that regularly alternate in playing a leading role in national governments - have been hurt in recent elections. The traditional centre-left parties in France and in the Netherlands have more or less disappeared and in Germany, France, Denmark, Italy and other countries new parties have disrupted the old order. The United Kingdom and the United States have not been exempt from disruptions of the same kind - witness Donald Trump and Brexit. This article is an attempt to determine the role that immigration has played in the recent transformation of politics in Western democracies. We utilize a unique seven nation data set (the United States, Canada, Denmark, France, Germany, Italy and the United Kingdom) created in the spring of 2015 and argue that immigration issues were at the heart of the changes we have observed in recent Western democratic elections.

Anxieties over immigration have risen sharply in recent years, and for most European countries we can use systematic survey data to date the increase to roughly 2012. Until then Eurobarometer respondents did not rank immigration as an important problem, while economic concerns and unemployment were much more frequently mentioned (European Commission, 2015). But most countries began experiencing a sharp increase in concern about immigration at that point. Eurobarometer data (from 2014 to 2017) show that Europeans generally tended to have quite negative attitudes toward immigrants from outside the EU while having (increasingly) positive attitudes toward immigrants from inside over these years (European Commission, 2018a; 2018b). It seems clear that immigration was a salient issue at the time of

(C) Società Italiana di Scienza Politica 2020. This is an Open Access article, distributed under the terms of the Creative Commons Attribution licence (http://creativecommons.org/licenses/by/4.0/), which permits unrestricted re-use, distribution, and reproduction in any medium, provided the original work is properly cited. 


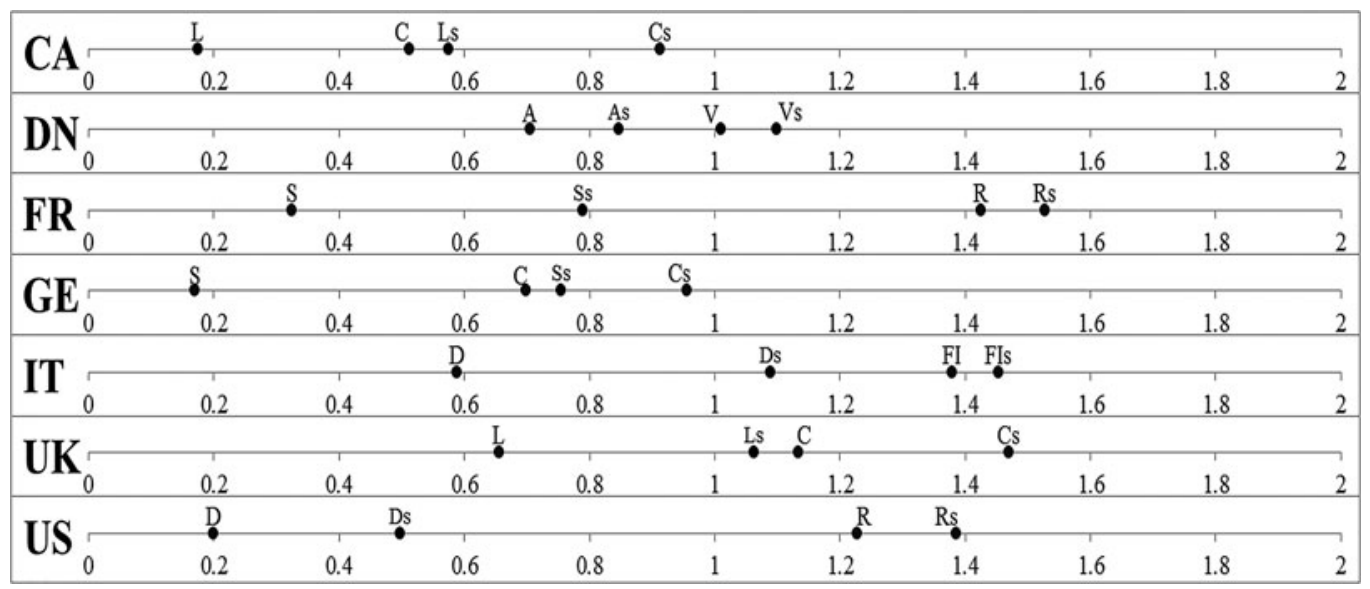

Figure 1. Average anti-immigration positions of partisans of mainstream parties (capital letters followed by the letter ' $s$ ') and average perceived positions of mainstream parties for its own partisans (plain capital letters) in various countries. In Canada the letter $\mathrm{C}$ stands for the Conservative Party and $\mathrm{L}$ is for the Liberal Party. In Denmark, the letter A is for the Social-Democratic Party and V for the right-wing party named Left, Denmark's Liberal Party. In France, S represents the Socialist Party, and R the Republicans. In Germany, S is for the SPD and C for the CDU-CSU. In Italy D represents the Democratic Party, and FI is for Go Italy. In the United Kingdom the letter L is for Labour Party, and the C for Conservative Party. In the United States D is for the Democratic Party, while R represents the Republican Party.

our cross-sectional survey and that it had, to some extent, partly surpassed concerns with unemployment. It is unclear whether this increase is attributable to a rise in actual levels of immigration, whether from inside or outside of Europe, to the continuing economic doldrums and the economic crises, especially in the less prosperous European countries, or to something else altogether. ${ }^{1}$

In spring 2015 an original comparative survey was conducted by YouGov allows us to investigate the effects of immigration attitudes on the political situations of Western democracies. The survey asked respondents two questions about immigration-related issues: the first about their views about the current level of immigrants and the second their general attitude towards immigrants already in the country. ${ }^{2}$ Since respondents had to place themselves as well as all relevant political parties in their country on these two policy dimensions, it is possible to place respondents' positions on immigration relative to where their parties are perceived on immigration, thus measuring perceived gaps between party positions and their partisans' positions. The results (see Figure 1) are that in every country the mainstream parties are perceived by their partisans to be more welcoming towards immigrants than their own partisans, and it is this representation gap which drives the article. Of course, as our data is cross-sectional, we cannot discuss over time variations and developments of this gap. Simply put, we observe that in spring 2015 the picture shows mainstream parties and their partisans quite far apart.

This article analyses the social, political and economic causes of the gap that empirically emerges between parties and voters on immigration, and it investigates its electoral consequence. Its original contribution lies in the merging of different strands of literature, such as studies looking at determinants of anti-immigrant attitudes and classical models of electoral behaviour, through an empirical investigation strategy featuring consistent individual-level measures for

\footnotetext{
${ }^{1}$ Eurobarometer data suggest that there may be a linkage between immigration attitudes and worries about terrorism. The Eurobarometer data show for example, that concern with terrorism was strongly correlated with concern about immigration the percent mentioning terrorism as one of the two most important problems facing Europe - rising from roughly $7 \%$ in 2012 to $44 \%$ in 2017. The corresponding numbers for immigration were $9 \%$ in 2012 and $38 \%$ in 2017 . At the level of individual countries, the same trends are apparent though there is considerable cross-country variation in the Eurobarometer series.

${ }^{2}$ Information on the data and measurement is reported in the Data and methods section (see below). See Appendix 1 for exact question wording.
} 
positions on immigration of both parties and voters in a cross-country comparative setting. In short, we confirm several previous findings concerning the determinants of anti-immigration positions, showing that culturally conservative and economically hurt voters are more likely to be more anti-immigrant than their party's official position. Perhaps the most important finding is that the representation gap on immigration issues has a significant impact on electoral results, in that parties are particularly likely to lose votes when they are more distant from their supporters on immigration issues.

The article is structured as follows. In the next two sections, we outline our main research questions and hypotheses, while discussing the relevant literatures. We then describe the dataset we employ for our empirical tests, and the specific methodological choices we made. Finally, we present and discuss the empirical evidence regarding the causes and the consequences of the representation gap on immigration. The conclusion follows.

\section{The sources of immigration attitudes: literature and hypotheses}

There are two questions we address in this article. First, how can we explain the immigration wedge between mainstream parties and their partisans? Second, what are the electoral consequences of this representation gap between parties and voters on immigration?

In order to address the aforementioned research questions, we need to discuss the possible explanations for the formation of anti-immigration attitudes proposed by the scientific literature (Citrin et al., 1997; Scheve and Slaughter, 2001; Borjas, 2003; McLaren, 2003; O’Rourke, 2003; Mayda, 2006; McLaren and Johnson, 2007). The sociological literature suggests that cultural and psychological variables are powerful predictors when explaining contemporary attitudes toward immigrants (Brader et al., 2008). Although both short and long-term economic forces can play a role, cultural anxieties and stereotypes remain the most important generator of anti-immigrant attitudes. ${ }^{3}$ Hainmueller and Hopkins (2014: 3), based on their survey of the literature, conclude that 'Overall, hypotheses grounded in self-interest have fared poorly, meaning that there is little accumulated evidence that citizens form their attitudes about immigration based on its effects on their personal economic situation. This pattern has held in both North America and Western Europe, in both observational and experimental studies'. Moreover, cultural attitudes toward diversity seem more important in explaining antiimmigrant attitudes than either private attitudes or sociotropic judgments. But cultural attitudes of the kind invoked here seem to be stable over time and unlikely, on that account, to explain change. Most of the relevant literature is based on cross-sectional studies; the rise of immigration as a salient issue, of explicitly anti-immigrant attitudes, and the political dislocations, has occurred over short time periods.

Economic literature, however, shows that immigration attitudes are related to economic vulnerability: 'People with higher levels of education and occupational skills are more likely to favour immigration regardless of the skill attributes of the immigrants in question' (Hainmueller and Hiscox, 2007: 399). ${ }^{4}$ Other studies have shown other ways that economics plays a role in shaping a country's views toward immigration (Malhotra et al., 2013). Indeed, economic theory gives powerful reasons that lowering tariff barriers (for example) can have adverse effects on some workers and their communities. ${ }^{5}$ Moreover, recent work suggests that these adverse effects increase relative to the aggregate benefits as the tariff barriers are reduced, which suggests that

\footnotetext{
${ }^{3}$ See the extensive survey of the literature Hainmueller and Hopkins (2014), which reports findings up to its publication date. For more recent research see Inglehart and Norris (2016). Their conclusions as to the relative importance of cultural and economic effects are similar.

${ }^{4}$ The effect of education on immigration attitudes appears to be complex. See Lancee and Sarrasin (2015).

${ }^{5}$ The classic statement of this idea is the Stolper-Samuelson theorem for a simple two factor economy, presented in Stolper and Samuelson (1941).
} 
globalization dynamics might naturally lead to an increase in anti-immigrant attitudes. ${ }^{6}$ It is very likely that negative economic outcomes reflect themselves in social and political attitudes, even if people misattribute the source of those outcomes. There is no reason to think, therefore, that the cross-sectional findings - that cultural attitudes are more powerful than narrow interest based economic attitudes in explaining 'who' is opposed to immigrants - are inconsistent with an economic account of the rise in anti-immigrant attitudes throughout the population. Moreover, it is difficult to cleanly separate economic from cultural effects. A substantial literature in political science suggests, for example, that people are likely to be guided in forming economic judgments by cultural or sociotropic considerations - how their nation or their community is doing economically - rather than by their own or their family's narrow interests (Kinder and Kiewiet, 1981). We think it is misleading, therefore, to infer from these findings that short run economic forces are unimportant causes of immigration attitudes.

Our main argument is that, in fact, the recent intensification of the immigration issue, which may be partly traced to cyclical economic effects, has had significant political consequences. We will show that the rise of anti-immigrant attitudes has exposed the vulnerability of mainstream political parties either to internal fracture or to entry by new parties or political leaders.

The relationship between anti-immigration attitudes and economic anxieties on the one hand, and cultural conservatism on the other, is something widely shown by recent empirical literature, as our brief literature review clearly reveals. ${ }^{7}$ However, in this article our analytic focus is not on attitudes on immigration issues held by voters per se, rather the focus is on how such individuallevel attitudes interplay with elite choices on immigration, and on the electoral consequences of this interplay. From this perspective, we believe the aforementioned literature provides useful insights into understanding what lies at the core of the phenomenon we highlight: the fact that mainstream parties are more pro-immigration than are their partisans. We show that the gap between voters and their parties on immigration plays a relevant role in the electoral setbacks experienced by those parties in recent years across the Western world. Using independent measures for past and present voting behaviour we show that further a partisan perceives the distance between herself and her party on immigration the greater the likelihood is that they will desert their party in a future election. The hypotheses to be tested cover both economic and cultural bases. Namely, they are as follows.

H1: We expect those who say that their economic situation is worse to be more anti-immigrant than the mainstream party they previously voted for.

$\mathrm{H} 2$ : We expect culturally conservative voters to be more anti-immigrant than the mainstream party they previously voted for.

\section{Immigration and voting: literature and hypotheses}

As anticipated, we are also interested in the electoral consequences of the strategic choices enacted by parties on the issue of immigration. We believe this constitutes an important contribution of this article, as in our view reactions toward immigrants have often been seen as not particularly relevant in terms of general electoral results, because of their low saliency, overshadowed by more salient domains - such as economic issues, for instance. This article shows that this perspective is

\footnotetext{
${ }^{6}$ Rodrik (2018) generalizes the Stolper-Samuelson result to complex economies and argues that its effects extend beyond the removal of tariff barriers to globalization more generally. He acknowledges that nations can adopt policies to compensate the 'losers' and notes that European welfare state policies have been more successful in moderating the effects of globalization in Europe compared with the United States. Indeed, he argues that recent pressures on welfare state protections may be the cause of increased anxieties over globalization in Europe.

${ }^{7}$ Furthermore, these claims have been corroborated with specific reference to the data at hand (Brady et al., 2016).
} 
in fact wrong. Possibly as a consequence of an increase in the saliency of immigration as an issue (Van der Brug et al., 2015), such reactions are now indeed very relevant for the whole of political systems, since they yield clear and large electoral consequences. Let us now briefly review classical approaches to electoral behaviour, and how they can relate to our study of the consequences of the immigration gap between mainstream parties and voters.

Political scientists have taken two general approaches to the study of voting behaviour. Following Downs (1957), who presented the classical motivation for prospective voting, the oldest tradition sees voting in elections as essentially forward looking. Voters were thought to vote for the option that would do the best job. This entailed forming beliefs as to what the candidates or the parties would do in the future. There is disagreement as to how such beliefs may be formed, especially depending on time and which side of the Atlantic is under investigation: would they depend on ideological leanings (Inglehart and Klingemann, 1976), party affiliations (Campbell et al., 1960; Bartle and Bellucci 2009), social groups (Lazarsfeld et al., 1944; Lipset and Rokkan, 1967; Bartolini and Mair, 1990) or promises on the stump (Bartels, 1993). But the essential point is that many scholars have thought that prospective voting is the way that any minimally rational voter would make decisions. ${ }^{8}$

This view is opposed by those who think that voting is essentially backward looking or retrospective. Key (1964) characterized voters as 'Gods of Vengeance and Reward'. By this account, when an incumbent candidate (or party) asks for her vote, the voter decides based on the past record rather than promises for the future. ${ }^{9}$ Since the contribution by Fiorina (1981) on retrospective voting, a significant amount of empirical research has indicated the importance of parties' past record on the electoral prospects of that party's candidates. In particular, scholars have repeatedly shown the role of the national economic performance in a comparative perspective (Lewis-Beck, 1988; Duch and Stevenson, 2008).

To be sure, these two models are not necessarily easy to tell apart: voters could use a party's past record to evaluate a party or they could use the past record to form beliefs about its likely future performance. Building on the insight of these seminal contributions about retrospective voting, we argue that the following hypotheses provide a robust test for the electoral effects of the representation gap on immigration:

H3: We expect that the more distant on immigration a voter is from the mainstream party she previously voted for the more likely she will not vote for that party in the future.

In addition to distance from their own preferred party (in retrospective terms, when considering whether to vote for it again or not), we think that the immigration attitudes might also be a relevant predictor of vote choice for any other party (in prospective terms, for instance when considering all available parties for the next elections). Thus,

H4: Regardless of the party voted for in previous elections, we expect that the more distant on immigration a voter is from a party the less likely she will be to vote for that party in the future.

\section{Data and methods}

To test our main hypotheses, we use data from the Italian Centre for Electoral Studies (CISE)-Hoover Institution Comparative Partisanship Survey. This is an original dataset that offers a unique perspective on the roots of the anti-immigrant reactions to the second globalization. From March to June of 2015, YouGov conducted a series of Computer-Assisted Web Interview surveys on samples of the voting-age population in seven nations (United States,

\footnotetext{
${ }^{8} \mathrm{~A}$ theory of prospective voting and a comparison with retrospective is presented in Fearon (1999).

${ }^{9} \mathrm{~A}$ theoretic approach is developed in Ferejohn (1986).
} 
Canada, United Kingdom, Denmark, Italy, France and Germany), asking identical questions to respondents about immigration and other issues. The national samples, each consisting of roughly 1000 cases, are representative of the national voting-age population for gender, age class, and region of residence. ${ }^{10}$ Obviously, the YouGov sample is a cross section, and so we can say little about attitude dynamics. However, the different countries were at different places in the business cycle in the spring of 2015 so that our measures of 'country effects' may incorporate some cyclic elements, though fixed effects can also pick up cultural or other intercountry differences. ${ }^{11}$ Given that the surveys were administered prior to the Syrian diaspora, our article might serve as a kind of baseline for future studies that might take account of more recent events.

The countries represented in the dataset vary widely in several important respects that might be relevant to immigration attitudes. Five are members of the EU (or were in 2015); the four countries on the European continent are inside both the Euro and Schengen areas. Three are, to some extent, committed to what is sometimes called the Anglo-Saxon model of 'flexible' labour markets and a common law legal system. The four continental countries have histories of relatively active government labour market policies. The electoral and party systems also vary widely: some countries use variants of majority or plurality rule to elect representatives and others employ forms of proportional representation. A case can be made that each country is 'exceptional' in some sense. But each also shares characteristics with others so that we can hope to isolate some effects that do not depend on particular country characteristics.

However, the unique feature of this study is found in the extensive battery of questions permitting respondents to place both themselves and the political parties on the same scales for each of several issues. Placement data will allow us to ask about the effects of immigration attitudes on placements, distances and, ultimately, on vote intentions. Moreover, as discussed above, we can carry out this assessment within the framework of the two prominent theories of voting found in the political science literature: prospective and retrospective voting models.

As anticipated earlier, this survey posed two questions about immigration. One question asks simply about the level of immigration, whether it should be decreased, kept the same or increased. The second question, which seems less sensitive to temporal variation and more focused on the respondent's view of her own society, concerns the degree to which immigrant residents should be integrated into society. In Table 1 we reported descriptive statistics for these two measures. Responses are dichotomized - with the anti-immigrant response coded as 1 . Table 1 also shows the frequency distribution for an index constructed by adding the two responses together. ${ }^{12}$

While there is significant cross-country variation in the responses, across the seven countries a majority agrees that the current level has to be decreased. Only in the two North American countries do majorities oppose decreasing immigration; even in those countries, more than $40 \%$ favour

\footnotetext{
${ }^{10}$ The representativeness of the voting-age population was achieved through quota sampling. YouGov maintains panels of several thousand electors in the various national cases included in our analyses, recruited via non-political websites through invitations and pop-up advertisements. Panelists were invited to participate to this survey until the necessary quotas were filled. In the different countries response rates varied, basically between $35 \%$ and $45 \%$ of invited panelists.

${ }^{11}$ For example, the economies in the United States, Canada, the United Kingdom and Germany were performing relatively well (overall) in that period while Italy and, to some extent, France were still mired in economic doldrums. On the other hand, there are significant regional variations within even well performing countries that need to be taken into account in future work on this sample of countries.

${ }^{12}$ To be clear, the first two variables are dummies separating respondents picking the anti-immigration stance (1) on that issues from those who do not (0). On each variable, respondents without a valid answer are not included percentages calculations. The index is a sum of these two dummies, counting how many times a respondent has taken the anti-immigration stance $(0,1$ or 2$)$. For the integration question, on which responses are measured on a 7 -point scale, we considered as antiimmigration respondents placing themselves on the 5, 6 or 7 points (all those more anti-integration than the central value of 4). For the level question, which has three possible responses (increase it, decrease it, and keep the current level), we considered as anti-immigration those respondents stating they want to decrease it (again, all those more anti-immigration than the central value - keep it as it is, in this instance). For the purpose of building the index, on each of the two immigration variables, respondents without a valid answer were considered as not having selected the anti-immigration stance (0).
} 
Table 1. Respondents' preferences on immigration items in the CISE-Hoover Institution Comparative Partisanship Survey

\begin{tabular}{|c|c|c|c|c|c|c|c|c|c|c|}
\hline & \multicolumn{3}{|c|}{$\begin{array}{c}\text { Encourage immigrants to } \\
\text { leave }\end{array}$} & \multicolumn{3}{|c|}{$\begin{array}{l}\text { Decrease current level of } \\
\text { immigration }\end{array}$} & \multicolumn{3}{|c|}{ Anti-immigration index } & \multirow[b]{2}{*}{$N$} \\
\hline & $\begin{array}{l}\text { Yes } \\
\%\end{array}$ & $\begin{array}{l}\text { No } \\
\%\end{array}$ & $\begin{array}{c}\text { Missing } \\
N\end{array}$ & $\begin{array}{l}\text { Yes } \\
\%\end{array}$ & $\begin{array}{l}\text { No } \\
\%\end{array}$ & $\begin{array}{c}\text { Missing } \\
N\end{array}$ & $\begin{array}{c}0 \\
\%\end{array}$ & $\begin{array}{l}1 \\
\%\end{array}$ & $\begin{array}{l}2 \\
\%\end{array}$ & \\
\hline Canada & 27.2 & 72.8 & 2 & 44.0 & 56.0 & 171 & 55.3 & 25.7 & 19.0 & 1047 \\
\hline Denmark & 41.2 & 58.8 & 9 & 63.7 & 36.3 & 81 & 23.6 & 53.5 & 22.9 & 1008 \\
\hline France & 50.0 & 50.0 & 17 & 70.3 & 29.7 & 168 & 30.5 & 29.3 & 40.2 & 1207 \\
\hline Germany & 37.4 & 62.6 & 13 & 59.7 & 40.3 & 88 & 40.2 & 28.3 & 31.5 & 1014 \\
\hline Italy & 45.6 & 54.4 & 4 & 72.8 & 27.3 & 72 & 23.3 & 41.3 & 35.4 & 1002 \\
\hline United Kingdom & 41.3 & 58.7 & 18 & 74.2 & 25.9 & 92 & 27.8 & 34.0 & 38.2 & 1126 \\
\hline Unites States & 38.8 & 61.2 & 4 & 48.0 & 52.0 & 164 & 46.5 & 28.2 & 25.2 & 1000 \\
\hline Overall & 40.4 & 59.6 & 67 & 62.5 & 37.5 & 836 & 35.2 & 34.2 & 30.7 & 7404 \\
\hline
\end{tabular}

Note: The anti-immigration index counts how many times respondent has taken the anti-immigration stance on the two immigration items (0, 1 or 2$)$

In empirical terms the two individual-level immigration items appear strongly correlated $(R=0.34)$, and Cronbach's alpha is above 0.5 , indicating that the two can (although barely) be represented by a unified index. However, we need to stress that this index is built for mere descriptive evidence and for the sake of synthesis here and in Figure 1. Two separate figures built on the two original items show the same pattern with mainstream parties more pro-immigrant than their partisans. See Figures B1 and B2 in the Appendix 2 . We do not argue that our index perfectly represents party position on the latent dimension of immigration. It simply represents a useful visualization of the immigration gap, the phenomenon we are interested in this study.

decreases in immigration. Germany, at almost $60 \%$ in favour of reducing the immigration, is next lowest, while France, Italy and the United Kingdom have over $70 \%$ of respondents agreeing that levels of immigration should be cut. With regard to integration of immigrants, again Canada is most inclined to favour integration over encouraging immigrants to leave, followed by Germany and the United States, with anti-immigration percentages below $40 \%$. All other countries are over 40 with France the highest at exactly $50 \%$.

As we have seen above, respondents had to place themselves on these two questions and then state where they perceived various political parties in their country to stand on the same immigration issues. Thus, responses to these survey items allow us to place respondents' positions on immigration relative to where their parties are perceived, which allows us to measure the representation gaps between party positions and their partisans' positions. ${ }^{13}$

In Figure 1 we graphically show, for the various countries, the average positions on the antiimmigration index for partisans of mainstream parties (capital letters followed by the letter ' $s$ ') and the average perceived positions of the same mainstream parties in the eyes of their own partisans (plain capital letters). The figure allows us to immediately understand, compare and contrast where parties and voters stand on immigration. For instance, we can see that on average US Democrats are quite liberal on immigration but that on average they perceive their party to be more liberal than they are, or we can grasp the degree of polarization on immigration in the different countries by looking at the distance between centre-left and centre-right voters and parties: minimal in Denmark, still small in countries like Italy and Canada (although with remarkably different centres of gravity - much more anti-immigrants in the former), very large in France.

Even more importantly to us, the data reported in Figure 1 let us highlight a striking fact, which is the starting point of our study: in every country, all mainstream parties have positioned (or, actually, are perceived as positioning themselves) as more pro-immigrant than their partisans. In all seven countries, both centre-right and centre-left mainstream parties are perceived as substantially more pro-immigrant than their own partisans. In some countries (Canada and the United Kingdom) both mainstream parties are perceived by their partisans as much more pro-immigrant than partisans of both parties, to the point that the relative mean values appear

\footnotetext{
${ }^{13}$ Partisans of a party are defined as those respondents declaring they feel particularly close to the party.
} 
statistically different. ${ }^{14}$ In other countries, like the United States and Italy, one mainstream party is more pro-immigrant than its own partisans to a statistical extent, while the other is less distant from its own partisans. Still, all 14 of the mainstream parties are more pro-immigrant than their own partisans: this generalized representation gap on immigration is the paramount information of interest emerging from Figure 1 for our investigation.

In order to assess the sources of the gap between voters and their own parties on immigration, we will assume that the deviations of interest are only those to the illiberal side of the party position and count those (few) who deviate in the liberal direction the same as those who continue to favour the position of their party. Thus, we run Tobit regressions, where only those who deviate in the illiberal direction take positive values, using standard socio-demographic measures, ideological preferences, economic evaluations and measures of cultural conservatism as predictors. The latter requires further discussion, while all other variables are standard measures. Our dataset includes two survey items regarding culturally conservative issues - namely, attitudes towards the death penalty and gay marriages. ${ }^{15}$ We acknowledge that these are not ideal indicators. Still, these are the only available measures in the dataset that are somewhat related to social issues. As our literature review has pointed to the relevance of cultural conservatism, we deem useful to include them as independent variables. In the end, we believe they can be meaningfully employed as adequate enough indicators for respondents' cultural conservatism, tapping into the civil rights and law-and-order dimensions of it. ${ }^{16}$

To empirically investigate the electoral consequences of the representation gap on immigration, as anticipated above, we will follow two alternative routes. First, we take a 'retrospective' view of elections and ask whether a party pays a price for being out of step with those who voted for it. We define party loyalty as the propensity to vote for the same party that constituents voted for last time and look only at loyalty to parties for various levels of immigration attitudes. We calculated how far a respondent is from her preferred party (the one voted in previous national general elections) and compare that against the frequency that they will vote for that party in the future. This measurement strategy is consistent with the concept of normal vote (Converse, 1966), the idea that voters will generally vote for their favoured party, although they might occasionally deviate from such behaviour. To be exhaustive, we need to point out that in two alternative ways to define party positions, the ones from which we compute respondent's distances. First, we simply looked at respondent's placement of the party. We call this 'subjective' distance. However, this measure presents two potential weaknesses. On the one hand, it is not available for those respondents failing to place their past-vote party. ${ }^{17}$ Secondly, it is prone to the rationalization issue - voters distancing themselves on the issue from a party they have decided not to vote. ${ }^{18}$ There is an alternative, which allows us to address both these issues. It consists of using the average placement of the party in the whole sample as the reference point from which we compute respondents' distances. We call this 'objective' distance. This way, all respondents are included in the analyses, provided that they placed themselves. Furthermore, it minimizes the rationalization issue, as each respondent is not able to distance herself from a party: she simply states her preferred position, and how far from the party this will be is not determined by her, but by the whole of the national respondents.

\footnotetext{
${ }^{14}$ See Table B1 in the Appendix 2.

${ }^{15}$ We built two dummy variables scoring 1 for respondent saying that the death penalty should be used and gay marriages should be repealed, respectively. Complete question wording is reported in the Appendix 1.

${ }^{16}$ In empirical terms, the two individual level items appear to be significantly correlated, but clearly two different things $(R$ $=0.18)$.

${ }^{17}$ This is a particularly relevant issue when distances on many issues are used in a single analysis, as in Table 6, as this strategy results in a significant drop in the number of observations included in the analysis.

${ }^{18}$ Nevertheless, it needs to be stressed that voting question were asked as final items in the surveys, precisely in order to minimize post-hoc rationalization effects.
} 
In addition to the retrospective voting approach, the second route is a prospective voting model. We assume that voters form future-oriented projections as to how the candidates would perform in office by using a simple spatial model. Vote propensity is a variable that allows the respondent to vote for any party with her reported propensity score. Thus, the data takes the form of a stacked data matrix. ${ }^{19}$ Because each respondent appears several times, as many as the parties she has validly assigned a vote propensity score to, we need to take account of correlation in the error structure. We run two ordered logit analyses of the propensity to vote for a party as a function of the distance between the party and the respondent on each issue. As a control, we include a Left-Right scale which, in principle, ought to be related to the spatial judgments. We also control for some plausible measures of cultural attitudes (the death penalty and gay marriages variable). ${ }^{20}$ Each analysis is clustered by respondent in order to correct for correlated errors.

\section{Findings: explaining the representation gap on immigration}

In this section we investigate which respondents' characteristics are linked to the distance from their own mainstream party on immigration issues. Table 2 presents the results separately for mainstream parties in government and in the opposition. Our findings provide a strong confirmation for $\mathrm{H} 1$ and particularly $\mathrm{H} 2$. Indeed, dissatisfaction with how the economy is doing and cultural conservatism do dispose people to deviate to the right of the previously voted party on immigration policy issues. We note that, even controlling for government evaluation, an economic evaluation (sociotropic or egotropic) exerts positive and significant effect on both the integration and the level variables for governing parties. On the contrary, we do not find significant effects of the economy on distance from opposition parties. Furthermore, the strong effects of cultural conservatism stand out. Both our indicators (death penalty and gay marriages) show extremely significant and positive effects on the distance to the right of the previously voted party, on both the integration and the level variables - regardless of the government/opposition condition of the party.

Beyond our hypothesis testing, Table 2 provides further evidence of interest. Country effects must be read as relative to Canada which is omitted from the regressions. The country effects are especially striking in the last column of the table, in which opposition parties in all the other nations exhibit smaller anti-immigrant gaps than did the Canadian opposition (the pro-immigrant Liberals who remained in opposition until October 2015). Also striking is the fact that governing parties in Denmark, France, Italy and the United States exhibit a very large gap on the preferred level of immigration. Liberal governing parties in these countries were unable to persuade their electoral base to support a pro-immigrant stance. Note that older people and females are more likely to prefer reducing the number of immigrants but are not necessarily opposed to integrating those who are already present into society. On the other hand, the effect of college, higher income or favourable evaluations of the government all reduce anti-immigration deviations.

The overall picture has become increasingly familiar with time. Liberal governing parties exhibit large gaps on immigration, whereas conservative parties in government (in Germany, Canada, the United Kingdom) are less vulnerable on the issue. At least this was so until the massive wave of Syrian immigrants began to appear in Europe.

\footnotetext{
${ }^{19}$ We use the 5 possible Expected-Vote-Frequency scores (see question wording in the Appendix 1) to create an ordinal vote-propensity variable for each party-respondent combination (the unit of analysis).

${ }^{20} \mathrm{~A}$ British commentator notes that 'Nobody has been out campaigning on [the death penalty], yet it strongly correlates with Brexit voting intention'. This speaks to a deeper personality dimension which social psychologists dub Right-Wing Authoritarianism (Altemeyer, 1988). A less judgmental way of thinking about RWA is order versus openness. The orderopenness divide is emerging as the key political cleavage, overshadowing the left-right economic dimension. This was noticed as early as the mid-1970s by Bell (1976), but has become more pronounced as the aging West's ethnic transformation has accelerated. See Kaufmann (2016). We think the same argument can be made for attitudes toward gay marriage as it is very likely to be connected to order-openness in Kaufmann's terms.
} 
Table 2. Tobit regressions of distances on immigration from previously voted mainstream parties on individual characteristics $^{a}$

\begin{tabular}{|c|c|c|c|c|c|c|c|c|}
\hline \multirow[b]{2}{*}{ Family worse off } & \multicolumn{2}{|c|}{$\begin{array}{c}\text { Government } \\
\text { mainstream party, } \\
\text { integration }\end{array}$} & \multicolumn{2}{|c|}{$\begin{array}{c}\text { Government } \\
\text { mainstream party, } \\
\text { level }\end{array}$} & \multicolumn{2}{|c|}{$\begin{array}{c}\text { Opposition } \\
\text { mainstream party, } \\
\text { integration }\end{array}$} & \multicolumn{2}{|c|}{$\begin{array}{c}\text { Opposition } \\
\text { mainstream party, } \\
\text { level }\end{array}$} \\
\hline & -0.027 & $(0.711)$ & $0.125^{\star}$ & $(0.036)$ & 0.088 & $(0.222)$ & 0.018 & $(0.718)$ \\
\hline Country worse off & $0.144^{\star}$ & $(0.049)$ & -0.069 & $(0.248)$ & 0.119 & $(0.111)$ & 0.035 & $(0.504)$ \\
\hline Death penalty: yes & $0.448^{\star \star \star}$ & $(0.000)$ & $0.310^{\star \star \star}$ & $(0.000)$ & $0.445^{\star \star \star}$ & $(0.000)$ & $0.293^{\star \star \star}$ & $(0.000)$ \\
\hline Gay marriages: no & $0.226^{\star \star \star}$ & $(0.000)$ & $0.143^{\star \star \star}$ & $(0.000)$ & $0.254^{\star \star \star}$ & $(0.000)$ & $0.114^{\star \star \star}$ & $(0.001)$ \\
\hline Ideological extremism & 0.002 & $(0.978)$ & -0.041 & $(0.411)$ & -0.027 & $(0.653)$ & $-0.197^{\star \star \star}$ & $(0.000)$ \\
\hline Government evaluation & $-0.204^{\star}$ & $(0.024)$ & $-0.216^{\star \star}$ & $(0.004)$ & $-0.202^{\star}$ & $(0.030)$ & $-0.159^{\star}$ & $(0.015)$ \\
\hline Age & -0.001 & $(0.359)$ & 0.000 & $(0.746)$ & 0.000 & $(0.889)$ & $0.004^{\star \star \star}$ & $(0.001)$ \\
\hline Male & $-0.086^{\star}$ & $(0.034)$ & $-0.090^{\star \star}$ & $(0.006)$ & -0.015 & $(0.716)$ & $-0.076^{\star \star}$ & $(0.006)$ \\
\hline College degree & $-0.140^{\star \star \star}$ & $(0.001)$ & $-0.110^{\star \star}$ & $(0.002)$ & $-0.134^{\star *}$ & $(0.002)$ & $-0.108^{\star \star \star}$ & $(0.000)$ \\
\hline Active worker & 0.003 & $(0.952)$ & -0.056 & $(0.194)$ & 0.003 & $(0.952)$ & 0.042 & $(0.237)$ \\
\hline $\begin{array}{l}\text { Family income } \\
\text { Canada }\end{array}$ & $-0.189^{\star}$ & $(0.023)$ & -0.001 & $(0.983)$ & -0.017 & $(0.839)$ & 0.009 & $(0.875)$ \\
\hline Denmark & $0.407^{\star \star \star}$ & $(0.000)$ & $0.414^{\star \star \star}$ & $(0.000)$ & $0.334^{\star \star \star}$ & $(0.000)$ & $-0.331^{\star \star \star}$ & $(0.000)$ \\
\hline France & 0.116 & $(0.165)$ & $0.427^{\star \star \star}$ & $(0.000)$ & -0.006 & $(0.939)$ & $-0.411^{\star \star \star}$ & $(0.000)$ \\
\hline Germany & 0.071 & $(0.395)$ & 0.034 & $(0.626)$ & 0.137 & $(0.122)$ & 0.006 & (0.923) \\
\hline Italy & 0.137 & $(0.097)$ & $0.312^{\star \star \star}$ & $(0.000)$ & 0.131 & $(0.127)$ & $-0.468^{\star \star \star}$ & $(0.000)$ \\
\hline United Kingdom & 0.138 & $(0.101)$ & 0.002 & $(0.975)$ & 0.123 & $(0.122)$ & $-0.120^{\star}$ & $(0.026)$ \\
\hline United States & 0.134 & $(0.073)$ & $0.362^{\star \star \star}$ & $(0.000)$ & $-0.328^{\star \star \star}$ & $(0.000)$ & $-0.561^{\star \star \star}$ & $(0.000)$ \\
\hline Constant & 0.054 & $(0.745)$ & $0.320^{\star}$ & $(0.019)$ & -0.261 & $(0.076)$ & $0.474^{\star \star \star}$ & $(0.000)$ \\
\hline Sigma constant & $0.623^{\star \star \star}$ & $(0.000)$ & $0.541^{\star \star \star}$ & $(0.000)$ & $0.543^{\star \star \star}$ & $(0.000)$ & $0.402^{\star \star \star}$ & $(0.000)$ \\
\hline N & 1263 & & 1263 & & 973 & & 973 & \\
\hline Pseudo $R^{2}$ & 0.096 & & 0.100 & & 0.134 & & 0.197 & \\
\hline
\end{tabular}

Notes: $P$-values, calculated with two-tailed tests, in parentheses; ${ }^{\star} P<0.05,{ }^{\star \star} P<0.01,{ }^{\star \star \star} P<0.001$; the pseudo $R{ }^{2}$ is McFadden.

${ }^{a}$ The models reported in Table 2 employ as DV the objective distances. As a robustness check we replicated these empirical tests employing the alternative subjective distances, which confirm the hypothesized effects of economic distress and conservatism on the immigration gap. Regression tables are reported in the Appendix 2 (see Table B2).

\section{Findings: the electoral consequences of the representation gap on immigration}

We now examine the effects that the representation gap on immigration has on electoral behaviour. As we have pointed out, the mainstream parties tend systematically to be more pro-immigrant than their own partisans. This seems to place them in a vulnerable position if popular attention to those issues increases. In the first model of this section, the question of how the immigration issue affects an individual's vote for his or her previously voted mainstream party is answered (Table 3).

To recall, we have two separate measures of the distance between respondent's and party's positions - one in which the latter is assessed by the respondent herself, and one in which it is measured as the average perceived party position across the whole sample. The results show that both distance on the immigration level and integration have independent negative and significant effects on vote propensity for the respondents' preferred party - no matter which alternative distances (objective or subjective) we look at. The further one is from the previously voted party on both immigration dimensions, the less likely she will be to vote for that party in future elections, as measured by the future vote propensity question. This appears as a strong empirical confirmation for $\mathrm{H} 3$.

Again, regardless of whether measured objectively or subjectively, the distance on the integration variable has a coefficient twice the size of the immigration level. It could be that this result is due to reactions to immigrants who are already in the country and are not yet fully assimilated from the viewpoint of the respondent, making the integration problem more immediate in time than future immigration. Subsequent work will have to determine whether that is true. It is, nevertheless, true that a retrospective model that places weight on immigration attitudes has 
Table 3. Effects on Vote Propensity for the mainstream party voted in previous general elections ${ }^{\mathrm{a}}$

\begin{tabular}{|c|c|c|c|c|}
\hline \multirow[b]{2}{*}{ Distance on immigrants' integration } & \multicolumn{2}{|c|}{ Objective distances } & \multicolumn{2}{|c|}{ Subjective distances } \\
\hline & $-0.439^{\star \star \star}$ & $(0.000)$ & $-0.552^{\star \star \star}$ & $(0.000)$ \\
\hline Distance on immigration level & $-0.213^{*}$ & $(0.030)$ & $-0.250^{\star \star \star}$ & $(0.000)$ \\
\hline Constant & -0.112 & $(0.668)$ & -0.031 & $(0.919)$ \\
\hline$N$ & 3899 & & 3048 & \\
\hline Pseudo $R^{2}$ & 0.196 & & 0.208 & \\
\hline
\end{tabular}

Notes: $P$-values, calculated with two-tailed tests, in parentheses; ${ }^{\star} P<0.05,{ }^{\star \star} P<0.01,{ }^{\star \star \star} P<0.001$; the pseudo $R^{2}$ is McFadden.

a Logistic regressions. Fixed effects and SES controls are omitted. We also included a PID dichotomy, scoring 1 if respondent declared voted party was the party she feels particularly close to, 0 otherwise. See question wording in the Appendix 1 . Country fixed effects are operationalized through country dummies. Full regression estimates are reported in the Appendix 2 (see Table B3). We replicated these regressions allowing both slopes and intercept to randomly vary by country in multi-level regression analyses. Findings are reported in the Appendix 2 (see Table B4) and generally confirm what is presented here.

explanatory power compared to models that do not. This is a warning to mainstream political leaders that deviating from party supporters' views on immigration (which are generally more conservative than party leaders) can threaten re-election.

We can now turn to a prospective voting model. Table 4 presents two ordered logit analyses of the propensity to vote for a party as a function of the distance between the party and the respondent on each issue. The left-hand column presents the results for objective distances - where we define the party position as the average placement of the party in the whole sample. The model employing subjective distances - the difference between the respondent's selfplacement and her placement of the party - is reported in the right-hand column. As above, we suppress the estimates of SES controls and country fixed effects. The last row of the table shows that respondent's distance from a party on the Left-Right dimension is a powerful predictor of vote propensities as would be expected if voting behaviour was largely driven by a one-dimensional model.

More importantly to our investigation, the results in Table 4 show that even after controlling for party-respondent distances on the Left-Right dimension, issue distances also have strong effects on the vote propensity, and this is particularly the case for the immigration issues. On both level and integration, the coefficients for party-respondent distance both objectively and

Table 4. Effects of party-respondent distances on Vote Propensity for a party ${ }^{a}$

\begin{tabular}{|c|c|c|c|c|}
\hline \multirow[b]{2}{*}{ Distance on: immigrants' integration } & \multicolumn{2}{|c|}{ Objective distances } & \multicolumn{2}{|c|}{ Subjective distances } \\
\hline & $-0.240^{\star * \star}$ & $(0.000)$ & $-0.315^{\star \star \star}$ & $(0.001)$ \\
\hline Distance on: immigration level & $-0.478^{\star \star \star}$ & $(0.000)$ & $-0.192^{\star \star}$ & $(0.007)$ \\
\hline Distance on: death penalty & -0.051 & $(0.192)$ & -0.060 & $(0.227)$ \\
\hline Distance on: gay marriages & $-0.166^{\star \star \star}$ & $(0.000)$ & -0.045 & $(0.353)$ \\
\hline Distance on: credit to foreign buyers & $-0.204^{\star}$ & $(0.018)$ & -0.029 & $(0.545)$ \\
\hline Distance on: income inequality & $-0.209^{\star \star}$ & $(0.002)$ & $-0.474^{\star \star \star}$ & $(0.000)$ \\
\hline Distance on: minimum wage & $-0.322^{\star \star \star}$ & $(0.000)$ & $-0.245^{\star \star}$ & $(0.001)$ \\
\hline Distance on: unemployment benefits & $-0.263^{\star \star \star}$ & $(0.000)$ & 0.007 & $(0.927)$ \\
\hline Distance on: firing employees & $-0.170^{\star \star}$ & $(0.008)$ & -0.126 & $(0.058)$ \\
\hline Distance on: governmental businesses & -0.051 & $(0.433)$ & $-0.108^{\star}$ & $(0.029)$ \\
\hline Distance on: retirement age & -0.055 & $(0.308)$ & -0.112 & $(0.090)$ \\
\hline Distance on: L/R dimension & $-1.299^{\star \star \star}$ & $(0.000)$ & $-1.163^{\star \star \star}$ & $(0.000)$ \\
\hline$N$ & 10,123 & & 3371 & \\
\hline Pseudo $R^{2}$ & 0.192 & & 0.239 & \\
\hline
\end{tabular}

Notes: $P$-values, calculated with two-tailed tests, in parentheses; ${ }^{\star} P<0.05,{ }^{\star \star} P<0.01,{ }^{\star \star \star} P<0.001$; the pseudo $R^{2}$ is McFadden. ${ }^{a}$ Ordered logistic regressions. Fixed effects and SES controls are omitted. Country fixed effects are operationalized through country dummies. Full results are reported in the Appendix 2 (See Table B5). Again, we replicated these regressions with multi-level regression analyses. Findings confirm what is presented here and are available on request. In the Appendix 2 we also report the country-specific models (Tables B6 and B7), which generally confirm the strength and significance of the effects of the immigration items - although with some exceptions. 
subjectively defined are highly significant. Furthermore, the only other specified issues for which this is true are income inequality, and minimum wage where the sign is also negative.

Thus, over nine issues, the two immigration questions each stand out separately, suggesting that not only is the electoral politics in these countries multi-dimensional, but also the effects of immigration attitudes emerge as real and powerful drivers of voting preferences, independent of traditional left-right party positions. These findings provide a robust validation for $\mathrm{H} 4$.

We suspect that this political configuration - in which the traditional parties seem unable to absorb new and important issues - may provide fertile soil for political realignment in some of the advanced democracies. There is an opening for political entrepreneurs to exploit the distance between voters and the mainstream parties on immigration, at least as long as the mainstream parties do not adjust their positions to bring them closer to their constituents. Of course it is also possible for the constituents to change their minds.

\section{Conclusion}

This article is motivated by some striking evidence emerging from an original comparative crossnational survey: all mainstream parties across the two sides of the Atlantic appear quite distant from their own voters on immigration issues. Basically, voters want fewer immigrants and to encourage those already in the country to leave compared to what their parties are offering them. Due to the limitations of our data, we do not know whether this gap has widened in recent times or it has long been there. In any case, this makes these parties vulnerable to competition from anti-immigrant parties, especially when immigration concerns intensify in saliency. Our study is dedicated to the assessment of the individual-level determinants of this gap, and on its electoral consequences.

We argued in the introduction that it is important to put the immigration issue in the context of the more general phenomenon of globalization which is, in its nature, a dynamic phenomenon. Globalization has two aspects: the first is economic, exposing local workers to world-wide labour markets and specifically to competition from workers in emerging nations (Brady et al., 2007; Spence, 2011). The second is cultural - by increasing diversity and threatening cultural norms and a sense of identity (Kriesi et al., 2006, 2008, 2012). Many studies suggest that the fear of diversity may be a very powerful determinant of immigration attitudes independent of economic factors (McLaren, 2003; McLaren and Johnson, 2007; Brader et al., 2008). ${ }^{21}$ But it is also true that people and communities are exposed differentially to the impacts of globalization and that national policies differ in how effectively these impacts are modulated (O'Rourke, 2003; Rodrik, 2018). These two phenomena are linked, of course, and nowhere more so than in immigration practice and policy (Scheve and Slaughter, 2001; Borjas, 2003; O'Rourke, 2003; Mayda, 2006; Bale, 2008; Van der Brug and Van Spanje, 2009; Van Spanje, 2010). We hasten to add, however, that immigrants in many countries are not the only (and perhaps not the most) important source of perceived diversity. In some countries, negative attitudes toward diversity may be driven by the presence of long-time citizens and other residents who have refused to assimilate, or been prevented from assimilating, to the majority culture, independently of immigration rates.

In this article we used a seven-nation survey to compare attitudes toward immigration held by voters and parties with regard to levels of immigration and integration of immigrants into the country. The results showed sharp differences across countries but, concerning the causes of the gap between mainstream parties and their (more anti-immigrant) voters, both economic frustration and even more so cultural conservatism appear to play a relevant role. Thus, our findings, concerning individual-level positions relative to the preferred political party, rather than plain voters' attitudes, are consistent with those of earlier work by Sides and Citrin (2007) who drew from a 2002-03 European Social Survey. They remark that 'at the individual level, cultural

\footnotetext{
${ }^{21}$ See also the recent findings in Inglehart and Norris (2016) as well as Brady et al. (2016).
} 
and national identity, economic interests and the level of information about immigration are all important predictors of attitude'. The similarity of our findings to the early studies is particularly noteworthy in view of the changed circumstances of the two surveys. Immigration is a much bigger issue now than it was then and its impact is probably felt differently in different countries.

Furthermore, we found that, with regard to economic measures, they are significant predictors of being more anti-immigrant than your own party only for parties in government. Indeed, if one believes that the economy is doing badly, this is likely to produce a wedge on immigration between her and her party if the party is in office.

The contribution of this article, however, is two-fold, as it does not stop at the causes of the gap between voters and mainstream parties on immigration, but looks at the electoral consequences of this gap. We estimated the effect that disagreement between respondents and parties on immigration issues exerts on voters' propensity to vote for parties they had previously supported, showing that parties lose votes because of their divergence from the immigration preferences of their previous supporters. This probably makes parties less willing to take pro-immigrant positions than they might otherwise be. In other words, even as parties reveal themselves as more pro-immigrant than their voters, this may actually understate the full degree of divergence present between party elites and supporters.

Moreover, when we analysed the respondent's vote propensities prospectively, the results showed that, even controlling for the traditional left-right factor and other issue preferences, immigration issues have a strong independent impact on future vote dispositions. Of course, we are not arguing that the issue of immigration exhausts the story about recent electoral change across the Western world. Nevertheless, these results - retrospective and prospective - raise the question of whether immigration has the chance to become a realigning issue in modern democracies. We can only raise that issue here without settling it. Our hope is that these results, particularly the political implications, can become a baseline for future research.

Besides the relevant social science implications of our study, there are also public policy implications which we deem noteworthy. There has been a powerful surge of anti-globalization political sentiment, which has spawned significant new political patterns: the President of the United States promises to erect protectionist barriers around the American economy; the British electorate voted to exit the European Union and across Europe anti-immigration parties and movements are rising. To some extent this is a bottom-up phenomenon, but new political leaders have begun to exploit it in ways that may threaten the post-war political consensus. It is important to understand where the opposition to immigration is coming from. This research shows that, in large part, those who perceive themselves or their national community as having lost out economically are more anti-immigrant. In addition, cultural conservatives are more anti-immigrant than are social liberals across all of our countries. Together, these groups appear to make up a large part of the electorate in many advanced democracies. The fact that all mainstream political parties in our study had taken positions that were more pro-immigration than their own partisans made them particularly vulnerable to anti-system or periphery parties. We will discuss the possible implications of this in a moment.

Before we do that, let us briefly look at how, on a different level, our findings can shed some light on our understanding of the fundamental concept of political representation. In particular, in terms of the responsibility vs. responsiveness dilemma introduced by Mair (2009).This problem is particularly challenging for mainstream parties in that, at least on immigration issues, mainstream parties are seen as not being responsive to the preferences of their own supporters; rather they appear to represent the general liberal values structuring the constitutional order of the Western world. ${ }^{22}$ This gap between responsiveness to Western world values and

\footnotetext{
${ }^{22}$ As Mair (2009) himself points out this dilemma goes back to the classical styles of representation - that is, delegates vs. trustees (Rehfeld, 2009). Thus, we could say that mainstream parties are proposing themselves to voters, at least on immigration, as trustees.
} 
representation of constituent views creates problems for mainstream parties. Our investigation clearly shows that the favour for responsibility over responsiveness is not in line with current voters' desires. One result is that voters are increasingly willing to abandon their mainstream parties the more they feel these parties are not representing them on immigration. The recent rise of populist parties, with their classical emphasis on how the will of the people has been manipulated by political elites, indicates that the problem of responsiveness and representation has implications broader than just immigration.

This brings us to some final considerations that our findings suggest in terms of party strategy dynamics. We have shown that mainstream parties were unable to align with their partisans on immigration, and how this costs them votes. This appears to confirm recent studies which indicate that mainstream parties are often unable to select the most efficient stances on issues, possibly because they are anchored to traditional ideological positions, which is in turn linked to poor electoral performances (Emanuele et al., 2020). In contrast, the same studies reveal that when mainstream parties are able to seize their opportunities, for instance abandoning classical pro-immigration positions, they can prevent their own electoral defeats and the 'populist drift' (De Sio and Weber, 2020). ${ }^{23}$

In conclusion, we argue that while it may be a good thing from a policy perspective that mainstream parties tend to take pro-global positions, the political consequences could be catastrophic. We have seen this movie before; it ended with isolation and beggar thy neighbour policies or with democratic collapse. Neither of the endings is very pleasant.

We do not relish playing Cassandra. But our research shows that many voters are willing to vote against parties they have supported in the past unless their party adjusts its position. Policy makers need to take heed of this and move cautiously lest they generate trends, which would be similar to those that ended the first transformation of the world economy. Immigration issues are especially treacherous now, when many of the major economies are mired in economic slowdowns and as the Middle Eastern wars have fuelled a flood of people seeking places in safer and more prosperous societies. Perhaps the best policy advice is to try to fix these issues without doing too much damage to our values or our economic prospects and hope that immigration politics will become less treacherous than they are today. As always, politics is the art of the possible. More than that is too much and too dangerous to wish.

Funding. The research received no grants from public, commercial or non-profit funding agency.

Data. The replication dataset is available at http://thedata.harvard.edu/dvn/dv/ipsr-risp.

Acknowledgements. Names are listed alphabetically. All authors contributed equally to the work. Previous versions of this article were presented at the LUISS workshop Turbulent times: Economic change and electoral instability in Western democracies, and the Freeman Spogli Institute (FSI) at Stanford. The authors would like to thank the anonymous reviewers for their useful remarks, along with Alessandro Chiaramonte, Roberto D’Alimonte, Lorenzo De Sio, Vincenzo Emanuele, Morris Fiorina, Hanspeter Kriesi, Pedro Magalhães, Leonardo Morlino, Douglas Rivers and Michael Spence for their helpful comments on earlier versions.

\section{References}

Altemeyer B (1988) Enemies of Freedom: Understanding Right-Wing Authoritarianism. San Francisco, CA: Jossey-Bass. Bale T (2008) Turning round the telescope. Centre-right parties and immigration and integration policy in Europe. Journal of European Public Policy 15, 315-330.

Bartels LM (1993) Messages received: the political impact of media exposure. American Political Science Review 87, $267-285$.

\footnotetext{
${ }^{23}$ For instance, this is the case of the Austrian ÖVP under Kurz's leadership (Plescia et al., 2020), or the VVD in the Netherlands over the past few years (Van Ditmars et al., 2020).
} 
Bartle J and Bellucci P (eds) (2009) Political Parties and Partisanship: Social Identity and Individual Attitudes. New York, NY: Routledge.

Bartolini S and Mair P (1990) Identity, Competition, and Electoral Availability. New York, NY: Cambridge University Press. Bell D (1976) The Cultural Contradictions of Capitalism. New York, NY: Basic Book.

Borjas G (2003) The labor demand curve is downward sloping: re-examining the impact of immigration on the labor market. Quarterly Journal of Economics 118, 1335-1374.

Brader T, Valentino NA and Suhay E (2008) What triggers public opposition to immigration? Anxiety, group cues, and immigration threat. American Journal of Political Science 52, 959-978.

Brady D, Beckfield J and Zhao W (2007) The consequences of economic globalization for affluent democracies. Annual Review of Sociology 33, 313-334.

Brady DW, Ferejohn JA and Paparo A (2016) Immigration Attitudes and the Politics of Globalization. Available at SSRN: https://ssrn.com/abstract=2820204 or http://dx.doi.org/10.2139/ssrn.2820204.

Campbell A, Converse PE, Miller WE and Stokes DE (1960) The American Voter. New York, NY: John Wiley \& Son.

Citrin J, Green DP, Muste C and Wong C (1997) Public opinion toward immigration reform: the role of economic motivations. The Journal of Politics 59, 858-881.

Converse PE (1966) The concept of a normal vote. In Campbell A, Converse PE, Miller WE and Stokes DE (eds), Elections and the Political Order. New York, NY: Wiley, pp. 9-39.

De Sio L and Weber T (2020) Issue yield, campaign communication, and electoral performance: a six-country comparative analysis. West European Politics 43(3), 720-745.

Downs A (1957) An Economic Theory of Democracy. New York, NY: Harper and Row.

Duch R and Stevenson R (2008) The Economic Vote: How Political and Economic Institutions Condition Election Results. Cambridge, UK: Cambridge University Press.

Emanuele V, Maggini N and Paparo A (2020) The times they are a-changin': party campaign strategies in the 2018 Italian election. West European Politics 43(3), 665-687.

European Commission (2015) Eurobarometer 78.1 (2012) TNS opinion, Brussels [producer]. GESIS Data Archive, Cologne. ZA5685 Data file Version 2.0.0, doi:10.4232/1.12061.

European Commission (2018a) Eurobarometer 82.3 (2014) TNS opinion, Brussels [producer]. GESIS Data Archive, Cologne. ZA5932 Data file Version 3.0.0, doi:10.4232/1.13021.

European Commission (2018b) Eurobarometer 88.3 (2017) TNS opinion, Brussels [producer]. GESIS Data Archive, Cologne. ZA6928 Data file Version 1.0.0, doi:10.4232/1.13007.

Fearon J (1999) Elections and representation. In Przeworski A, Stokes S and Manin B (eds), Democracy, Accountability, and Representation. Cambridge, UK: Cambridge University Press, pp. 29-54.

Ferejohn J (1986) Incumbent performance and electoral control. Public Choice 50, 5-25.

Fiorina MP (1981) Retrospective Voting in American National Elections. New Haven, CT: Yale University Press.

Hainmueller J and Hiscox MJ (2007) Educated preferences: explaining attitudes toward immigration in Europe. International Organization 61, 399-442.

Hainmueller J and Hopkins DJ (2014) Public attitudes toward immigration. Annual Review of Political Science 17, 225-249.

Inglehart R and Klingemann H (1976) Party identification, ideological preference and the left-right dimension among western mass publics. In Budge I, Crewe I and Farlie D (eds), Party Identification and Beyond. New York, NY: Wiley, pp. 243273.

Inglehart $\mathbf{R}$ and Norris $\mathbf{P}$ (2016) Trump, Brexit, and the rise of populism: economic have-nots and cultural backlash. Harvard Kennedy School Faculty Research Working Paper Series.

Kaufmann E (2016) It's NOT the economy, stupid: Brexit as a story of personal values. British Politics and Policy at LSE.

Key VO (1964) Politics, Parties and Pressure Groups, 5th Edn. New York, NY: Crowell.

Kinder DR and Kiewiet DR (1981) Sociotropic politics: the American case. British Journal of Political Science 11, $129-161$.

Kriesi H-P, Grande E, Lachat R, Dolezal M, Bornschier S and Frey T (2006) Globalization and the transformation of the national political space: six European countries compared. European Journal of Political Research 45, 921-956.

Kriesi H-P, Grande E, Lachat R, Dolezal M, Bornschier S and Frey T (2008) West European Politics in the Age of Globalization. Cambridge, UK: Cambridge University Press.

Kriesi H-P, Grande E, Lachat R, Dolezal M, Bornschier S and Frey T (2012) Political Conflict in Western Europe. Cambridge, UK: Cambridge University Press.

Lancee B and Sarrasin O (2015) Educated preferences or selection effects? A longitudinal analysis of the impact of educational attainment on attitudes towards immigrants. European Sociological Review 31, 490-501.

Lazarsfeld P, Berelson B and Gaudet H (1944) The People's Choice: How the Voter Makes up His Mind in a Presidential Campaign. New York, NY: Columbia University Press.

Lewis-Beck MS (1988) Economics and Elections: The Major Western Democracies. Ann Arbor, MI: University of Michigan Press. 
Lipset SM and Rokkan S (1967) Cleavage structures, party systems and voter alignments: an introduction. In Lipset SM and Rokkan S (eds), Party Systems and Voter Alignments. New York, NY: Free Press, pp. 1-64.

Mair P (2009) Representative versus responsible government. MplfG Working Paper 09/8.

Malhotra N, Margalit Y and Mo CH (2013) Economic explanations for opposition to immigration: distinguishing between prevalence and conditional impact. American Journal of Political Science 57, 391-410.

Mayda AM (2006) Who is against immigration? A cross-country investigation of individual attitudes toward immigrants. Review of Economics and Statistics 88, 510-530.

McLaren LM (2003) Anti-immigrant prejudice in Europe: contact, threat perception, and preferences for the exclusion of migrants. Social Forces 81, 909-936.

McLaren LM and Johnson M (2007) Resources, group conflict and symbols: explaining anti-immigration hostility in Britain. Political Studies 55, 709-732.

O'Rourke K (2003) Heckscher-Ohlin theory and individual attitudes towards globalization. National Bureau of Economic Research, No. w9872.

Plescia C, Kritzinger S and Oberluggauer P (2020) 'Parties' issue strategies on the drawing board: the 2017 Austrian case. West European Politics 43(3), 639-664.

Rehfeld A (2009) Representation rethought: on trustees, delegates, and gyroscopes in the study of political representation and democracy. American Political Science Review 103, 214-230.

Rodrik D (2018) Populism and the economics of globalization. Journal of International Business Policy 1, 12-33.

Scheve KF and Slaughter MJ (2001) Labor market competition and individual preferences over immigration policy. Review of Economics and Statistics 83, 133-145.

Sides J and Citrin J (2007) European opinion about immigration: the role of identities, interests and information. British Journal of Political Science 37, 477-504.

Spence M (2011) The Next Convergence: The Future of Economic Growth in a Multispeed World. New York: Farrar, Straus and Giroux.

Stolper W and Samuelson P (1941) Protection and real wages. Review of Economic Studies 9, 58-73.

Van der Brug W and Van Spanje J (2009) Immigration, Europe and the 'new' cultural dimension. European Journal of Political Research 48, 309-334.

Van der Brug W, D’Amato G, Ruedin D and Berkhout J (2015) The Politicisation of Migration. London: Routledge.

Van Ditmars MM, Maggini N and Van Spanje J (2020) Small winners and big losers: strategic party behaviour in the 2017 Dutch general election. West European Politics 43(3), 543-564.

Van Spanje J (2010) Contagious parties: anti-immigration parties and their impact on other parties' immigration stances in contemporary Western Europe. Party Politics 16, 563-586.

\section{Appendix 1}

\section{Question wordings in the CISE-Hoover institution comparative partisanship survey Immigration items [anti-immigration index]}

What is [your/party's] position on immigration?

\begin{tabular}{llllllll}
\hline 1 & 2 & 3 & 4 & 5 & 6 & 7
\end{tabular}

Help integrate immigrants into [national] society

Encourage immigrants to leave [country]

Do (you/party) think current levels of immigration into [country] should be changed?

(Increased/Kept the same/Decreased)

\section{Perceptions of the economy [economic performance index]}

Over the last 12 months has the [national] economy...

(Gotten better/Stayed about the same/Gotten worse)

And over the last 12 months has your own family's financial situation...

(Gotten better/Stayed about the same/Gotten worse)

What is the current unemployment rate in [country]?

Please tell us the percentage of adults who want to work that are currently unemployed and looking for a job. If you don't know, please make your best guess.

How would you describe this level of unemployment?

(Very high/Somewhat high/Normal/Somewhat low/Very low/Don't know) 


\section{Vote propensity [expected-vote-frequency]}

In the future, how often do you think you will vote for (candidates from) the following political parties?

(Always/Most of the times/About half of the times/Occasionally/Never)

\section{Left/right self-placement and party placement}

Where would you place [yourself/party] on the following 7-point scale?

\begin{tabular}{lllllll}
\hline 1 & 2 & 3 & 4 & 5 & 6 & 7 \\
Left & & & & Right
\end{tabular}

\section{Party-closeness}

Do you consider yourself to be close to any particular party?

Follow-up questions only for respondents answering 'Yes' to the previous question:

Which party do you feel close to? [Open-ended answer. Only one answer is possible]

Do you feel yourself to be very close to this party, fairly close or merely a sympathizer?

\section{Cultural conservatism}

Should two people of the same sex be permitted to marry?

(Yes/No/Don't know)

Should the death penalty be used for some serious crimes, such as pre-meditated murder or acts of terrorism that cause multiple deaths?

(Yes/No/Don't know)

\section{Appendix 2}

\section{Additional figures and tables}

Table B1. Average anti-immigration positions of partisans of mainstream parties and average perceived positions of mainstream parties for its own partisans in various countries

\begin{tabular}{|c|c|c|c|c|c|c|c|c|}
\hline \multirow{3}{*}{$\begin{array}{l}\text { Country } \\
\text { Canada }\end{array}$} & \multirow{3}{*}{$\begin{array}{l}\text { Party } \\
\text { Party }\end{array}$} & \multicolumn{3}{|c|}{$\begin{array}{l}\text { Partisans position on the } \\
\text { anti-immigration index }\end{array}$} & \multicolumn{3}{|c|}{$\begin{array}{l}\text { Party position on the } \\
\text { anti-immigration index }\end{array}$} & \multirow{3}{*}{$\frac{N}{69}$} \\
\hline & & \multirow{2}{*}{$\frac{\text { Mean value }}{0.575}$} & \multicolumn{2}{|c|}{$\begin{array}{c}95 \% \\
\text { confidence } \\
\text { interval }\end{array}$} & \multirow{2}{*}{$\begin{array}{c}\text { Mean value } \\
0.174\end{array}$} & \multicolumn{2}{|c|}{$\begin{array}{c}95 \% \\
\text { confidence } \\
\text { interval }\end{array}$} & \\
\hline & & & 0.400 & 0.751 & & 0.059 & 0.289 & \\
\hline & Conservative Party & 0.912 & 0.752 & 1.072 & 0.512 & 0.352 & 0.671 & 98 \\
\hline \multirow[t]{2}{*}{ Denmark } & Social-Democratic Party & 0.847 & 0.739 & 0.955 & 0.706 & 0.555 & 0.857 & 110 \\
\hline & Liberal Party & 1.099 & 0.950 & 1.248 & 1.010 & 0.852 & 1.168 & 85 \\
\hline \multirow[t]{2}{*}{ France } & Socialist Party & 0.790 & 0.630 & 0.949 & 0.324 & 0.205 & 0.443 & 101 \\
\hline & The Republicans & 1.528 & 1.403 & 1.653 & 1.425 & 1.292 & 1.558 & 124 \\
\hline \multirow[t]{2}{*}{ Germany } & SPD & 0.754 & 0.559 & 0.949 & 0.169 & 0.070 & 0.268 & 79 \\
\hline & CDU-CSU & 0.955 & 0.802 & 1.107 & 0.698 & 0.551 & 0.846 & 126 \\
\hline \multirow[t]{2}{*}{ Italy } & Democratic Party & 1.089 & 0.986 & 1.192 & 0.589 & 0.491 & 0.686 & 177 \\
\hline & Go Italy & 1.454 & 1.285 & 1.623 & 1.379 & 1.173 & 1.585 & 54 \\
\hline \multirow[t]{2}{*}{ UK } & Labour Party & 1.062 & 0.942 & 1.182 & 0.655 & 0.533 & 0.776 & 170 \\
\hline & Conservative Party & 1.470 & 1.343 & 1.597 & 1.133 & 0.988 & 1.278 & 113 \\
\hline \multirow[t]{2}{*}{ US } & Democratic Party & 0.497 & 0.413 & 0.581 & 0.200 & 0.139 & 0.262 & 273 \\
\hline & Republican Party & 1.385 & 1.280 & 1.489 & 1.228 & 1.104 & 1.353 & 188 \\
\hline
\end{tabular}




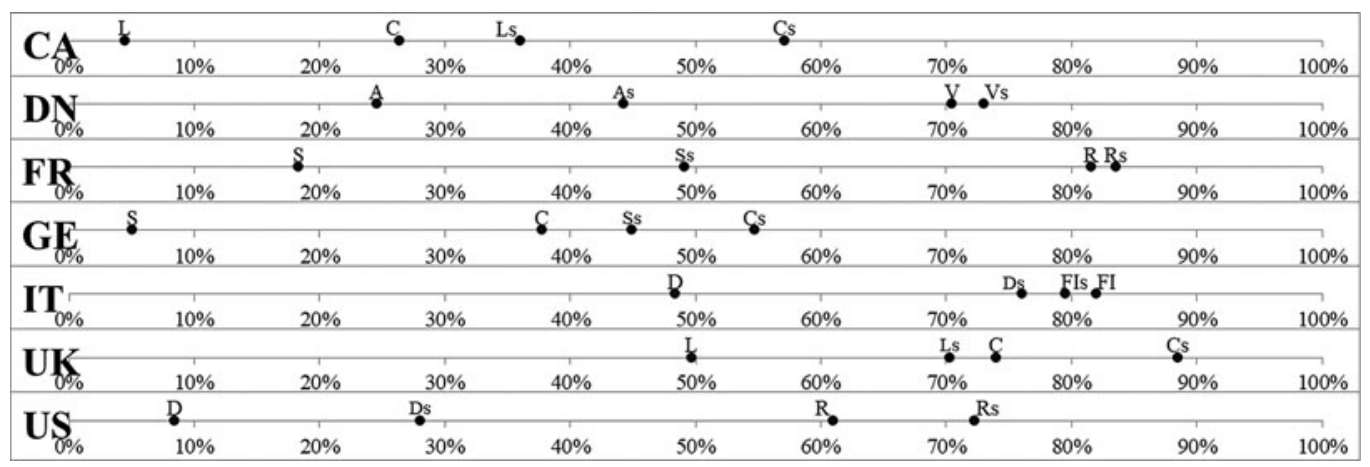

Figure B1. Percentage of partisans of mainstream parties (capital letters followed by the letter ' $\mathrm{s}$ ') stating they want to reduce the immigration level and average perceived positions on the level variable of mainstream parties for its own partisans (plain capital letters) in various countries. In Canada the letter $C$ stands for the Conservative Party and $L$ is for the Liberal Party. In Denmark, the letter A is for the Social-Democratic Party and V for the right-wing party named Left, Denmark's Liberal Party. In France, S represents the Socialist Party and R the Republicans. In Germany, $\mathrm{S}$ is for the SPD and C for the CDU-CSU. In Italy D represents the Democratic Party and FI is for Go Italy. In the United Kingdom the letter $L$ is for Labour Party and the C for Conservative Party. In the United States D is for the Democratic Party, while R represents the Republican Party. The same legend is applied in Figure B2.

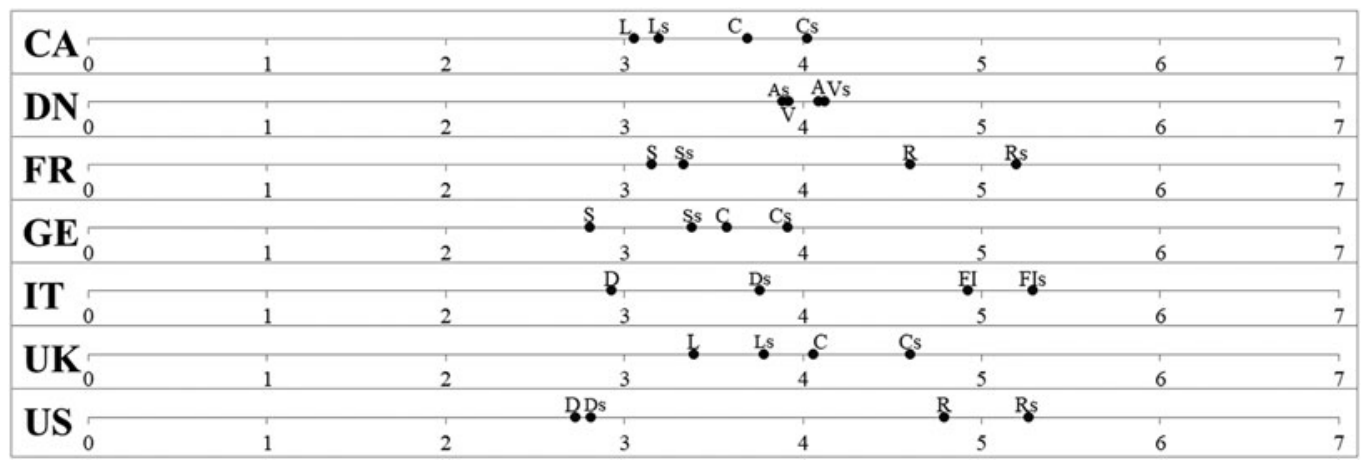

Figure B2. Average positions on the integration variable for partisans of mainstream parties (capital letters followed by the letter ' $s$ ') and average perceived positions on the integration variable of mainstream parties for its own partisans (plain capital letters) in various countries.

Notes: $0=$ Help integrate immigrants into [national] society; $7=$ Encourage immigrants to leave [country]. 
Table B2. Tobit regressions of subjective distances on immigration from mainstream parties on individual characteristics

\begin{tabular}{|c|c|c|c|c|c|c|c|c|}
\hline \multirow[b]{2}{*}{ Family worse off } & \multicolumn{2}{|c|}{$\begin{array}{c}\text { Government } \\
\text { mainstream party, } \\
\text { integration }\end{array}$} & \multicolumn{2}{|c|}{$\begin{array}{c}\text { Government } \\
\text { mainstream party, } \\
\text { level }\end{array}$} & \multicolumn{2}{|c|}{$\begin{array}{c}\text { Opposition } \\
\text { mainstream party, } \\
\text { integration }\end{array}$} & \multicolumn{2}{|c|}{$\begin{array}{c}\text { Opposition } \\
\text { mainstream party, } \\
\text { level }\end{array}$} \\
\hline & $0.204^{\star \star}$ & $(0.009)$ & $0.398^{\star}$ & $(0.015)$ & 0.048 & $(0.566)$ & 0.177 & $(0.403)$ \\
\hline Country worse off & -0.116 & $(0.133)$ & 0.012 & $(0.940)$ & -0.138 & $(0.106)$ & 0.174 & $(0.427)$ \\
\hline Death penalty: yes & $0.190^{\star * *}$ & $(0.000)$ & $0.392^{\star \star \star}$ & $(0.000)$ & $0.137^{\star \star}$ & $(0.008)$ & 0.161 & $(0.213)$ \\
\hline Gay marriages: no & $0.129^{\star \star}$ & $(0.008)$ & 0.066 & $(0.517)$ & 0.037 & $(0.492)$ & 0.115 & $(0.400)$ \\
\hline Ideological extremism & -0.011 & $(0.861)$ & -0.203 & $(0.134)$ & 0.017 & $(0.817)$ & -0.352 & $(0.054)$ \\
\hline Government evaluation & $-0.386^{\star \star *}$ & $(0.000)$ & $-0.942^{\star \star \star}$ & $(0.000)$ & -0.040 & $(0.705)$ & 0.189 & $(0.466)$ \\
\hline Age & -0.000 & $(0.847)$ & -0.000 & $(0.909)$ & $0.004^{\star}$ & $(0.021)$ & 0.000 & $(0.981)$ \\
\hline Male & -0.065 & $(0.131)$ & $-0.211^{\star}$ & $(0.019)$ & 0.084 & $(0.068)$ & -0.078 & $(0.505)$ \\
\hline College degree & -0.015 & $(0.732)$ & $-0.234^{\star}$ & $(0.013)$ & $0.104^{\star}$ & $(0.030)$ & 0.196 & $(0.111)$ \\
\hline Active worker & 0.024 & $(0.663)$ & $0.270^{\star}$ & $(0.021)$ & $0.131^{*}$ & $(0.028)$ & $0.442^{\star \star}$ & $(0.004)$ \\
\hline Family income & -0.153 & $(0.083)$ & -0.102 & $(0.580)$ & -0.136 & $(0.165)$ & -0.419 & $(0.097)$ \\
\hline \multicolumn{9}{|l|}{ Country } \\
\hline Denmark & 0.172 & $(0.083)$ & $0.460^{\star}$ & $(0.025)$ & -0.085 & $(0.387)$ & $-0.553^{\star}$ & $(0.027)$ \\
\hline France & -0.054 & $(0.569)$ & -0.104 & $(0.595)$ & -0.118 & $(0.237)$ & $-0.604^{\star}$ & $(0.016)$ \\
\hline Germany & 0.069 & $(0.452)$ & 0.066 & $(0.732)$ & 0.048 & $(0.644)$ & 0.112 & (0.658) \\
\hline Italy & -0.014 & $(0.880)$ & -0.198 & $(0.309)$ & 0.015 & $(0.884)$ & $-0.562^{\star}$ & $(0.038)$ \\
\hline United Kingdom & 0.132 & $(0.162)$ & $-0.419^{\star}$ & $(0.040)$ & 0.123 & $(0.204)$ & 0.047 & $(0.842)$ \\
\hline United States & -0.076 & $(0.382)$ & 0.173 & $(0.332)$ & 0.002 & $(0.987)$ & -0.271 & $(0.260)$ \\
\hline Constant & $0.561^{\star \star}$ & $(0.002)$ & 0.599 & $(0.108)$ & -0.102 & $(0.546)$ & -0.345 & $(0.426)$ \\
\hline Sigma constant & $0.621^{\star \star *}$ & $(0.000)$ & $1.200^{\star \star \star}$ & $(0.000)$ & $0.589^{\star \star \star}$ & $(0.000)$ & $1.330^{\star \star \star}$ & $(0.000)$ \\
\hline$N$ & 1015 & & 1015 & & 775 & & 775 & \\
\hline Pseudo $R^{2}$ & 0.047 & & 0.050 & & 0.027 & & 0.032 & \\
\hline
\end{tabular}

Notes: $P$-values, calculated with two-tailed tests, in parentheses; ${ }^{*} P<0.05,{ }^{* \star} P<0.01,{ }^{* *} P<0.001$; the pseudo $R^{2}$ is McFadden 
Table B3. Effects on Vote Propensity for the party voted in previous general elections, full models

\begin{tabular}{|c|c|c|c|c|}
\hline \multirow[b]{2}{*}{ Distance on integration } & \multicolumn{2}{|c|}{ Objective distances } & \multicolumn{2}{|c|}{ Subjective distances } \\
\hline & $-0.439^{\star \star \star}$ & $(0.000)$ & $-0.552^{\star \star \star}$ & $(0.000)$ \\
\hline Distance on immigration level & $-0.213^{\star}$ & $(0.030)$ & $-0.250^{\star \star \star}$ & $(0.000)$ \\
\hline \multicolumn{5}{|l|}{ Age class } \\
\hline \multicolumn{5}{|l|}{ Less than 30} \\
\hline $30 / 44$ & 0.183 & $(0.174)$ & 0.205 & (0.196) \\
\hline $45 / 64$ & $0.399^{\star \star}$ & $(0.002)$ & $0.440^{\star \star}$ & $(0.003)$ \\
\hline 65 or more & $0.606^{\star \star \star}$ & $(0.000)$ & $0.603^{\star \star \star}$ & $(0.000)$ \\
\hline Gender (male) & 0.070 & $(0.373)$ & 0.094 & $(0.303)$ \\
\hline \multicolumn{5}{|l|}{ Education level } \\
\hline \multicolumn{5}{|l|}{ No high school degree } \\
\hline High school degree & 0.111 & $(0.415)$ & 0.085 & $(0.587)$ \\
\hline Some college & $0.558^{\star}$ & $(0.025)$ & $0.561^{*}$ & $(0.046)$ \\
\hline I-level college degree & -0.071 & $(0.640)$ & -0.023 & (0.879) \\
\hline II-level college degree & 0.221 & $(0.143)$ & 0.223 & $(0.192)$ \\
\hline Post-university degree & 0.172 & $(0.387)$ & 0.065 & $(0.769)$ \\
\hline \multicolumn{5}{|l|}{ Family income } \\
\hline \multicolumn{5}{|l|}{ Missing } \\
\hline Less than $20,000 \$, £$ or $€$ & -0.085 & $(0.585)$ & -0.281 & $(0.122)$ \\
\hline Between $20,000 \$, £$ or $€$ and $49,999 \$$, $£$ or $€$ & -0.064 & $(0.642)$ & -0.196 & $(0.226)$ \\
\hline Between $50,000 \$, £$ or $€$ and $99,999 \$$ or $€$ & -0.035 & $(0.815)$ & -0.171 & $(0.335)$ \\
\hline More than $1,000,000 \$, £$ or $€$ & 0.082 & $(0.684)$ & -0.043 & (0.857) \\
\hline \multicolumn{5}{|l|}{ Country } \\
\hline \multicolumn{5}{|l|}{ Canada } \\
\hline Denmark & -0.060 & $(0.682)$ & 0.034 & $(0.852)$ \\
\hline France & $-0.380^{\star \star}$ & $(0.008)$ & $-0.405^{\star}$ & $(0.022)$ \\
\hline Germany & -0.045 & $(0.777)$ & -0.013 & $(0.944)$ \\
\hline Italy & $-0.574^{\star \star \star}$ & $(0.000)$ & $-0.498^{\star \star}$ & $(0.007)$ \\
\hline United Kingdom & $0.309^{\star}$ & $(0.048)$ & $0.447^{\star}$ & $(0.019)$ \\
\hline United States & $0.362^{*}$ & $(0.024)$ & $0.410^{\star}$ & $(0.034)$ \\
\hline PID with party voted in previous elections & $2.277^{\star \star \star}$ & $(0.000)$ & $2.212^{\star \star \star}$ & $(0.000)$ \\
\hline Constant & -0.112 & $(0.668)$ & -0.031 & $(0.919)$ \\
\hline N & 3899 & & 3048 & \\
\hline Pseudo $R^{2}$ & 0.196 & & 0.208 & \\
\hline
\end{tabular}

Notes: $P$-values, calculated with two-tailed tests, in parentheses; ${ }^{\star} P<0.05,{ }^{\star \star} P<0.01,{ }^{\star \star \star} P<0.001$; the pseudo $R^{2}$ is McFadden. 
Table B4. Effects on Propensity-To-Vote for the party voted in previous general elections (country random slopes and intercepts)

\begin{tabular}{|c|c|c|c|c|}
\hline \multirow[b]{2}{*}{ Distance on integration } & \multicolumn{2}{|c|}{ Objective distances } & \multicolumn{2}{|c|}{ Subjective distances } \\
\hline & $-0.448^{\star \star}$ & $(0.005)$ & $-0.481^{\star \star \star}$ & $(0.000)$ \\
\hline Distance on immigration level & -0.170 & $(0.192)$ & $-0.249^{\star \star \star}$ & $(0.001)$ \\
\hline \multicolumn{5}{|l|}{ Age class } \\
\hline \multicolumn{5}{|l|}{ Less than 30} \\
\hline $30 / 44$ & 0.178 & $(0.186)$ & 0.207 & $(0.194)$ \\
\hline $45 / 64$ & $0.409^{\star \star}$ & $(0.001)$ & $0.445^{\star \star}$ & (0.003) \\
\hline 65 or more & $0.616^{\star \star \star}$ & $(0.000)$ & $0.607^{\star \star \star}$ & $(0.000)$ \\
\hline Gender (male) & 0.074 & $(0.351)$ & 0.096 & (0.292) \\
\hline \multicolumn{5}{|l|}{ Education level } \\
\hline \multicolumn{5}{|l|}{ No high school degree } \\
\hline High school degree & 0.103 & $(0.451)$ & 0.074 & $(0.639)$ \\
\hline Some college & $0.557^{\star}$ & $(0.025)$ & $0.557^{\star}$ & $(0.047)$ \\
\hline I-level college degree & -0.077 & $(0.614)$ & -0.047 & $(0.787)$ \\
\hline Il-level college degree & 0.215 & $(0.155)$ & 0.207 & $(0.229)$ \\
\hline Post-university degree & 0.168 & $(0.396)$ & 0.045 & $(0.840)$ \\
\hline \multicolumn{5}{|l|}{ Family income } \\
\hline \multicolumn{5}{|l|}{ Missing } \\
\hline Less than $20,000 \$, £$ or $€$ & -0.088 & $(0.575)$ & -0.272 & $(0.139)$ \\
\hline Between $20,000 \$, £$ or $€$ and $49,999 \$, £$ or $€$ & -0.080 & (0.558) & -0.204 & (0.209) \\
\hline Between $50,000 \$, £$ or $€$ and $99,999 \$$ or $€$ & -0.046 & (0.758) & -0.168 & $(0.343)$ \\
\hline More than $1,000,000 \$, £$ or $€$ & 0.083 & $(0.678)$ & -0.034 & $(0.886)$ \\
\hline PID with party voted in previous elections & $2.280^{\star \star \star}$ & $(0.000)$ & $2.221^{\star \star \star}$ & $(0.000)$ \\
\hline Constant & -0.189 & (0.493) & 0.013 & (0.968) \\
\hline var(distance_integration[country]) Constant & 0.088 & $(0.321)$ & 0.126 & $(0.348)$ \\
\hline var(distance_level[country]) Constant & 0.044 & $(0.439)$ & 0.049 & $(0.481)$ \\
\hline $\operatorname{var}($ constant [country]) Constant & 0.115 & $(0.170)$ & 0.131 & $(0.189)$ \\
\hline$N$ & 3899 & & 3048 & \\
\hline Pseudo $R^{2}$ & 0.225 & & 0.238 & \\
\hline
\end{tabular}

Notes: $P$-values, calculated with two-tailed tests, in parentheses; ${ }^{\star} P<0.05,{ }^{\star \star} P<0.01,{ }^{\star \star \star} P<0.001$; the pseudo $R^{2}$ is McFadden. 
Table B5. Effects of party-respondent distances on Vote Propensity for a party, full models

\begin{tabular}{|c|c|c|c|c|}
\hline \multirow[b]{2}{*}{ Distance on: integration } & \multicolumn{2}{|c|}{ Objective distances } & \multicolumn{2}{|c|}{ Subjective distances } \\
\hline & $-0.240^{\star \star \star}$ & $(0.000)$ & $-0.315^{\star \star \star}$ & $(0.001)$ \\
\hline Distance on: immigration level & $-0.478^{\star \star \star}$ & $(0.000)$ & $-0.192^{\star \star}$ & $(0.007)$ \\
\hline Distance on: death penalty & -0.051 & $(0.192)$ & -0.060 & $(0.227)$ \\
\hline Distance on: gay marriages & $-0.166^{\star \star \star}$ & $(0.000)$ & -0.045 & $(0.353)$ \\
\hline Distance on: credit to foreign buyers & $-0.204^{\star}$ & $(0.018)$ & -0.029 & $(0.545)$ \\
\hline Distance on: income inequality & $-0.209^{\star \star}$ & $(0.002)$ & $-0.474^{\star \star \star}$ & $(0.000)$ \\
\hline Distance on: minimum wage & $-0.322^{\star \star \star}$ & $(0.000)$ & $-0.245^{\star \star}$ & $(0.001)$ \\
\hline Distance on: unemployment benefits & $-0.263^{\star \star \star}$ & $(0.000)$ & 0.007 & $(0.927)$ \\
\hline Distance on: firing employees & $-0.170^{\star \star}$ & $(0.008)$ & -0.126 & $(0.058)$ \\
\hline Distance on: governmental businesses & -0.051 & $(0.433)$ & $-0.108^{\star}$ & $(0.029)$ \\
\hline Distance on: retirement age & -0.055 & $(0.308)$ & -0.112 & $(0.090)$ \\
\hline Distance on: $L / R$ dimension & $-1.299^{\star \star \star}$ & $(0.000)$ & $-1.163^{\star \star \star}$ & $(0.000)$ \\
\hline PID with target party & $3.390^{\star \star \star}$ & $(0.000)$ & $2.619^{\star \star \star}$ & $(0.000)$ \\
\hline Governing party & $0.327^{\star \star \star}$ & $(0.000)$ & $0.389^{\star \star \star}$ & $(0.000)$ \\
\hline \multicolumn{5}{|l|}{ Age class } \\
\hline \multicolumn{5}{|l|}{ Less than 30} \\
\hline $30 / 44$ & -0.142 & $(0.162)$ & -0.228 & (0.189) \\
\hline $45 / 64$ & $-0.309^{\star \star \star}$ & $(0.001)$ & $-0.404^{\star *}$ & $(0.007)$ \\
\hline 65 or more & $-0.428^{\star \star \star}$ & $(0.000)$ & $-0.623^{\star \star \star}$ & $(0.000)$ \\
\hline Gender (male) & -0.014 & $(0.783)$ & 0.036 & $(0.736)$ \\
\hline \multicolumn{5}{|l|}{ Education level } \\
\hline \multicolumn{5}{|l|}{ No high school degree } \\
\hline High school degree & -0.056 & $(0.546)$ & -0.122 & (0.498) \\
\hline Some college & $-0.422^{\star \star}$ & $(0.004)$ & $-0.697^{\star}$ & $(0.013)$ \\
\hline I-level college degree & -0.128 & $(0.203)$ & -0.110 & $(0.567)$ \\
\hline II-level college degree & $-0.273^{\star \star}$ & $(0.005)$ & -0.273 & $(0.128)$ \\
\hline Post-university degree & $-0.278^{\star}$ & $(0.028)$ & -0.324 & $(0.168)$ \\
\hline \multicolumn{5}{|l|}{ Family income } \\
\hline \multicolumn{5}{|l|}{ Missing } \\
\hline Less than $20,000 \$, £$ or $€$ & $0.291^{\star \star}$ & $(0.004)$ & 0.357 & $(0.115)$ \\
\hline Between $20,000 \$$, $£$ or $€$ and $49,999 \$, £$ or $€$ & 0.165 & $(0.051)$ & $0.419^{\star}$ & $(0.033)$ \\
\hline Between $50,000 \$, £$ or $€$ and $99,999 \$$ or $€$ & 0.144 & $(0.108)$ & 0.318 & $(0.122)$ \\
\hline More than $1,000,000 \$, £$ or $€$ & 0.121 & $(0.325)$ & 0.496 & $(0.061)$ \\
\hline \multicolumn{5}{|l|}{ Country } \\
\hline \multicolumn{5}{|l|}{ Canada } \\
\hline Denmark & $-0.919^{\star \star \star}$ & $(0.000)$ & $-0.764^{\star \star \star}$ & $(0.000)$ \\
\hline France & $-0.338^{\star \star \star}$ & $(0.001)$ & -0.138 & $(0.483)$ \\
\hline Germany & $-0.491^{\star \star \star}$ & $(0.000)$ & -0.342 & $(0.062)$ \\
\hline Italy & $-0.294^{\star \star}$ & $(0.006)$ & -0.037 & $(0.855)$ \\
\hline United Kingdom & $-0.543^{\star \star \star}$ & $(0.000)$ & -0.088 & (0.669) \\
\hline United States & $0.614^{\star \star \star}$ & $(0.000)$ & $0.907^{\star \star \star}$ & $(0.000)$ \\
\hline Cut1_Constant & $-2.273^{\star \star \star}$ & $(0.000)$ & $-1.709^{\star \star \star}$ & $(0.000)$ \\
\hline Cut2_ Constant & $-1.075^{\star \star \star}$ & $(0.000)$ & -0.603 & $(0.094)$ \\
\hline Cut3_Constant & $-0.442^{*}$ & $(0.033)$ & 0.032 & $(0.929)$ \\
\hline Cut4_Constant & $1.170^{\star \star \star}$ & $(0.000)$ & $1.502^{\star \star \star}$ & $(0.000)$ \\
\hline$N$ & 10,123 & & 3371 & \\
\hline Pseudo $R^{2}$ & 0.192 & & 0.239 & \\
\hline
\end{tabular}

Notes: $P$-values, calculated with two-tailed tests, in parentheses; ${ }^{\star} P<0.05,{ }^{\star \star} P<0.01,{ }^{\star \star \star} P<0.001$; the pseudo $R^{2}$ is McFadden. 
Table B6. Effects of party-respondent objective distances on Vote Propensity for a party by country

\begin{tabular}{|c|c|c|c|c|c|c|c|}
\hline & Canada & Denmark & France & Germany & Italy & UK & US \\
\hline Distance on: integration & 0.159 & $0.636^{\star \star \star}$ & $-0.667^{\star \star \star}$ & $-0.327^{+}$ & $-0.352^{*}$ & $-0.699^{\star \star \star}$ & $-0.523^{\star}$ \\
\hline $\begin{array}{l}\text { Distance on: immigration } \\
\text { level }\end{array}$ & -0.207 & $-0.864^{\star \star \star}$ & $-0.768^{\star \star \star}$ & $-0.340^{\star}$ & $0.422^{*}$ & $-0.388^{\star}$ & -0.218 \\
\hline Distance on: death penalty & -0.077 & -0.085 & -0.191 & -0.067 & 0.047 & -0.164 & -0.161 \\
\hline Distance on: gay marriages & -0.130 & -0.013 & $-0.467^{\star \star \star}$ & -0.092 & $-0.222^{*}$ & -0.097 & $-0.424^{\star \star \star}$ \\
\hline $\begin{array}{l}\text { Distance on: credit to } \\
\text { foreign buyers }\end{array}$ & -0.287 & 0.234 & 0.152 & $-0.546^{\star \star}$ & $-0.507^{\star}$ & 0.019 & 0.154 \\
\hline $\begin{array}{l}\text { Distance on: income } \\
\text { inequality }\end{array}$ & $-0.613^{\star \star}$ & -0.155 & 0.277 & -0.149 & $-0.496^{\star}$ & $-0.405^{\star}$ & $-0.401^{+}$ \\
\hline Distance on: minimum wage & $-1.015^{\star \star \star}$ & -0.006 & -0.154 & -0.136 & -0.199 & $-0.588^{\star \star}$ & $-0.708^{\star \star \star}$ \\
\hline $\begin{array}{l}\text { Distance on: unemployment } \\
\text { benefits }\end{array}$ & -0.113 & $-0.260^{+}$ & $-0.281^{+}$ & -0.145 & 0.019 & $-0.508^{\star \star}$ & $-0.649^{\star \star \star}$ \\
\hline $\begin{array}{l}\text { Distance on: firing } \\
\text { employees }\end{array}$ & -0.146 & -0.028 & $-0.341^{\star}$ & 0.145 & $-0.274^{+}$ & -0.309 & -0.029 \\
\hline $\begin{array}{l}\text { Distance on: governmental } \\
\text { businesses }\end{array}$ & -0.001 & $-0.362^{\star \star}$ & $-0.952^{\star \star \star}$ & $0.611^{\star \star \star}$ & $0.554^{\star}$ & -0.051 & 0.228 \\
\hline Distance on: retirement age & 0.161 & -0.090 & -0.082 & -0.265 & $-0.436^{\star}$ & $0.242^{+}$ & 0.061 \\
\hline Distance on: L/R dimension & $-0.389^{+}$ & $-1.994^{\star \star *}$ & $-0.929^{\star \star \star}$ & $-1.072^{\star \star \star}$ & $-1.496^{\star \star \star}$ & $-1.473^{\star \star \star}$ & -0.321 \\
\hline PID with target party & $3.464^{\star \star \star}$ & $3.815^{\star \star \star}$ & $3.362^{\star \star \star}$ & $3.335^{\star \star \star}$ & $3.258^{\star \star \star}$ & $3.797^{\star \star \star}$ & $2.679^{\star \star \star}$ \\
\hline Governing party & $0.250^{+}$ & $0.242^{+}$ & $0.212^{+}$ & $0.374^{\star}$ & $0.259^{*}$ & $0.593^{\star \star \star}$ & 0.228 \\
\hline \multicolumn{8}{|l|}{ Age class } \\
\hline \multicolumn{8}{|l|}{ Less than 30} \\
\hline $30 / 44$ & $-0.541^{+}$ & 0.075 & 0.223 & $-0.559^{*}$ & -0.224 & -0.311 & -0.092 \\
\hline $45 / 64$ & $-0.461^{+}$ & $0.359^{+}$ & -0.205 & $-0.672^{\star}$ & $-0.582^{\star}$ & $-0.393^{+}$ & -0.052 \\
\hline 65 or more & $-0.516^{+}$ & 0.218 & $-0.430^{+}$ & $-0.843^{\star \star}$ & $-0.979^{\star * \star}$ & $-0.477^{\star}$ & 0.021 \\
\hline Gender (male) & 0.120 & -0.041 & -0.009 & -0.191 & -0.008 & 0.126 & 0.058 \\
\hline \multicolumn{8}{|l|}{ Education level } \\
\hline \multicolumn{8}{|l|}{ No high school degree } \\
\hline High school degree & $-0.561^{\star}$ & -0.136 & -0.336 & 0.123 & -0.277 & -0.157 & $0.863^{*}$ \\
\hline Some college & - & - & - & - & $-0.599^{+}$ & 0.269 & 0.309 \\
\hline I-level college degree & $-0.464^{+}$ & -0.142 & $-0.532^{+}$ & 0.0762 & -0.472 & -0.139 & 0.255 \\
\hline II-level college degree & $-0.517^{+}$ & -0.231 & $-0.719^{\star}$ & -0.139 & $-0.547^{+}$ & -0.080 & 0.386 \\
\hline Post-university degree & -0.413 & $-0.779^{\star \star}$ & $-0.985^{\star \star}$ & - & $-0.715^{+}$ & -0.204 & 0.597 \\
\hline \multicolumn{8}{|l|}{ Family income } \\
\hline \multicolumn{8}{|l|}{ Missing } \\
\hline Less than $20,000 \$, £$ or $€$ & 0.177 & 0.140 & $0.641^{\star}$ & 0.153 & -0.269 & 0.157 & 0.290 \\
\hline $\begin{array}{l}\text { Between } 20,000 \$, £ \text { or } € \\
\text { and } 49,999 \$, £ \text { or } €\end{array}$ & 0.179 & 0.027 & $0.437^{+}$ & 0.160 & $-0.403^{\star}$ & 0.083 & $0.479^{+}$ \\
\hline $\begin{array}{l}\text { Between } 50,000 \$ \text {, } £ \text { or } € \\
\text { and } 99,999 \$ \text { or } €\end{array}$ & -0.102 & 0.026 & $0.839^{\star \star}$ & 0.269 & -0.384 & -0.195 & $0.414^{+}$ \\
\hline $\begin{array}{l}\text { More than } 1,000,000 \$, £ \\
\text { or } €\end{array}$ & -0.219 & $-0.438^{+}$ & 0.996 & $0.697^{+}$ & 0.463 & 0.270 & 0.381 \\
\hline Cut1_Constant & $-2.604^{\star \star \star}$ & -0.660 & $-2.728^{\star \star \star}$ & $-1.631^{\star \star}$ & $-2.598^{\star \star \star}$ & $-1.992^{\star \star \star}$ & $-1.961^{\star \star}$ \\
\hline Cut2_ Constant & $-1.178^{+}$ & 0.832 & $-1.619^{\star \star}$ & -0.425 & $-1.594^{\star \star}$ & -0.724 & -0.529 \\
\hline Cut3_Constant & -0.402 & $1.336^{\star}$ & $-1.080^{\star}$ & 0.207 & -0.817 & -0.199 & 0.333 \\
\hline Cut4_Constant & $1.604^{\star \star}$ & $2.971^{\star \star \star}$ & 0.221 & $1.637^{\star \star}$ & 0.840 & $1.555^{\star \star}$ & $2.374^{\star \star \star}$ \\
\hline$N$ & 1026 & 1994 & 1928 & 1535 & 1637 & 1290 & 713 \\
\hline Pseudo $R^{2}$ & 0.127 & 0.233 & 0.220 & 0.142 & 0.209 & 0.231 & 0.236 \\
\hline
\end{tabular}

Notes: ${ }^{+} P<0.1 ;{ }^{\star} P<0.05,{ }^{\star \star} P<0.01,{ }^{\star \star \star} P<0.001$; the pseudo $R^{2}$ is McFadden. 
Table B7. Effects of party-respondent subjective distances on Vote Propensity for a party by country

\begin{tabular}{|c|c|c|c|c|c|c|c|}
\hline & Canada & Denmark & France & Germany & Italy & UK & US \\
\hline Distance on: integration & 0.167 & $-0.562^{\star}$ & -0.262 & -0.021 & $-0.536^{\star}$ & $-0.608^{\star}$ & $-0.604^{\star}$ \\
\hline Distance on: immigration level & -0.011 & $-0.588^{\star \star}$ & $-0.403^{\star}$ & -0.146 & 0.091 & -0.329 & $-0.432^{+}$ \\
\hline Distance on: death penalty & -0.001 & 0.054 & $-0.253^{*}$ & -0.011 & 0.036 & 0.041 & -0.180 \\
\hline Distance on: gay marriages & -0.052 & $0.277^{+}$ & 0.009 & -0.058 & $-0.193^{+}$ & -0.026 & $-0.435^{\star \star}$ \\
\hline $\begin{array}{l}\text { Distance on: credit to foreign } \\
\text { buyers }\end{array}$ & 0.109 & 0.013 & -0.061 & -0.052 & $-0.203^{+}$ & 0.117 & -0.095 \\
\hline Distance on: income inequality & $-0.627^{\star}$ & -0.388 & $-0.516^{\star}$ & $-0.371^{+}$ & $-0.712^{\star \star}$ & -0.355 & -0.235 \\
\hline Distance on: minimum wage & $-0.531^{\star}$ & $-0.453^{\star}$ & -0.096 & $-0.534^{\star \star}$ & -0.015 & $-0.441^{+}$ & $-0.531^{+}$ \\
\hline $\begin{array}{l}\text { Distance on: unemployment } \\
\text { benefits }\end{array}$ & -0.099 & 0.057 & 0.171 & 0.179 & -0.047 & $-0.344^{+}$ & 0.127 \\
\hline Distance on: firing employees & -0.042 & 0.032 & -0.292 & 0.048 & $-0.391^{*}$ & -0.186 & -0.029 \\
\hline $\begin{array}{l}\text { Distance on: governmental } \\
\text { businesses }\end{array}$ & -0.185 & -0.105 & $-0.209^{+}$ & 0.065 & $-0.215^{+}$ & 0.029 & -0.033 \\
\hline Distance on: retirement age & $-0.647^{+}$ & -0.114 & -0.016 & -0.215 & 0.065 & 0.128 & $-0.653^{\star *}$ \\
\hline Distance on: L/R dimension & $-0.957^{\star \star}$ & $-2.175^{\star \star \star}$ & $-1.267^{\star \star \star}$ & $-1.017^{\star \star \star}$ & $-1.098^{\star \star \star}$ & $-1.003^{\star \star}$ & $-1.202^{\star \star \star}$ \\
\hline PID with target party & $2.898^{\star \star \star}$ & $2.974^{\star \star \star}$ & $2.457^{\star \star \star}$ & $2.979^{\star \star \star}$ & $2.373^{\star \star \star}$ & $3.193^{\star \star \star}$ & $1.896^{\star \star \star}$ \\
\hline Governing party & 0.397 & 0.333 & 0.232 & $0.678^{\star \star}$ & $0.848^{\star \star \star}$ & $0.445^{+}$ & 0.031 \\
\hline \multicolumn{8}{|l|}{ Age class } \\
\hline \multicolumn{8}{|l|}{ Less than 30} \\
\hline $30 / 44$ & -0.078 & -0.119 & -0.025 & $-0.772^{+}$ & -0.695 & 0.253 & -0.329 \\
\hline $45 / 64$ & -0.274 & 0.377 & -0.564 & $-0.726^{\star}$ & $-1.831^{\star \star \star}$ & -0.016 & 0.460 \\
\hline 65 or more & -0.440 & -0.367 & $-0.686^{+}$ & $-0.730^{+}$ & $-2.139^{\star \star \star}$ & -0.296 & 0.287 \\
\hline Gender (male) & 0.321 & -0.274 & -0.094 & 0.221 & 0.047 & -0.274 & 0.128 \\
\hline \multicolumn{8}{|l|}{ Education level } \\
\hline \multicolumn{8}{|l|}{ No high school degree } \\
\hline High school degree & $-0.948^{+}$ & $-1.194^{+}$ & 0.097 & 0.007 & 0.158 & -0.472 & -0.215 \\
\hline Some college & - & - & - & - & -0.447 & $0.968^{\star}$ & -1.019 \\
\hline I-level college degree & -0.930 & -0.987 & -0.105 & 0.281 & -0.472 & -0.239 & -0.970 \\
\hline II-level college degree & -0.738 & -0.771 & -0.158 & -0.114 & $-0.827^{+}$ & 0.134 & -0.474 \\
\hline Post-university degree & -0.427 & $-2.192^{\star \star \star}$ & -0.629 & - & -0.751 & -0.232 & -0.540 \\
\hline \multicolumn{8}{|l|}{ Family income } \\
\hline \multicolumn{8}{|l|}{ Missing } \\
\hline Less than $20,000 \$, £$ or $€$ & -0.591 & 0.467 & 0.510 & 0.476 & $-1.403^{\star \star}$ & 0.187 & 0.013 \\
\hline $\begin{array}{l}\text { Between } 20,000 \$ \text {, } £ \text { or } € \text { and } \\
49,999 \$, £ \text { or } €\end{array}$ & -0.039 & 0.558 & 0.446 & $0.720^{*}$ & $-1.064^{\star}$ & -0.303 & 0.606 \\
\hline $\begin{array}{l}\text { Between } 50,000 \$, £ \text { or } € \text { and } \\
99,999 \$ \text { or } €\end{array}$ & -0.210 & 0.321 & 0.804 & 0.431 & $-1.233^{\star}$ & -0.556 & 0.746 \\
\hline More than $1,000,000 \$, £$ or $€$ & -0.201 & -0.277 & 0.857 & $1.651^{\star \star}$ & 1.113 & -0.090 & 0.681 \\
\hline Cut1_Constant & $-2.407^{+}$ & $-2.738^{\star \star}$ & $-1.729^{+}$ & -0.482 & $-4.354^{\star \star \star}$ & $-2.327^{\star}$ & $-4.283^{\star \star \star}$ \\
\hline Cut2_Constant & -1.155 & -1.087 & -0.697 & 0.631 & $-3.312^{\star \star \star}$ & -1.146 & $-2.783^{\star}$ \\
\hline Cut3_Constant & -0.434 & -0.516 & -0.256 & $1.253^{+}$ & $-2.408^{\star \star}$ & -0.398 & -1.580 \\
\hline Cut4_Constant & 1.383 & 0.868 & 1.080 & $2.712^{\star \star \star}$ & -0.872 & 1.399 & 0.348 \\
\hline$N$ & 256 & 585 & 775 & 641 & 510 & 341 & 263 \\
\hline Pseudo $R^{2}$ & 0.203 & 0.294 & 0.258 & 0.172 & 0.278 & 0.290 & 0.383 \\
\hline
\end{tabular}

Notes: ${ }^{+} P<0.1 ;{ }^{\star} P<0.05,{ }^{\star \star} P<0.01,{ }^{\star \star \star} P<0.001$; the pseudo $R^{2}$ is McFadden.

Cite this article: Brady DW, Ferejohn JA, Paparo A (2020). 'Are we losing touch?' Mainstream parties' failure to represent their voters on immigration and its electoral consequences. Italian Political Science Review/Rivista Italiana di Scienza Politica 50, 398-421. https://doi.org/10.1017/ipo.2019.42 